\title{
Nanopesticides: A Systematic Review of Their Prospects With Special Reference to Tea Pest Management
}

\author{
Bhabesh Deka ${ }^{*}$, Azariah Babu ${ }^{1}$, Chittaranjan Baruah ${ }^{2}$ and Manash Barthakur ${ }^{3}$ \\ ${ }^{1}$ North Bengal Regional Research and Development Centre, Nagrakata, India, ${ }^{2}$ Postgraduate Department of Zoology, \\ Darrang College (Affiliated to Gauhati University), Tezpur, India, ${ }^{3}$ Department of Zoology, Pub Kamrup College, Baihata \\ Chariali, India
}

OPEN ACCESS

Edited by:

Marcin Frankowski,

Adam Mickiewicz University, Poland

Reviewed by:

Mario D'amico,

University of Catania, Italy

Sapna Langyan,

National Bureau of Plant Genetic

Resources (ICAR), India

*Correspondence:

Bhabesh Deka

bhabesh.deka@gmail.com

Specialty section:

This article was submitted to

Nutrition and Sustainable Diets,

a section of the journal

Frontiers in Nutrition

Received: 26 March 2021

Accepted: 08 June 2021

Published: 10 August 2021

Citation:

Deka B, Babu A, Baruah C and Barthakur M (2021) Nanopesticides: A Systematic Review of Their Prospects

With Special Reference to Tea Pest Management. Front. Nutr. 8:686131.

doi: 10.3389/fnut.2021.686131
Background: Tea is a natural beverage made from the tender leaves of the tea plant (Camellia sinensis Kuntze). Being of a perennial and monoculture nature in terms of its cultivation system, it provides a stable micro-climate for various insect pests, which cause substantial loss of crop. With the escalating cost of insect pest management and increasing concern about the adverse effects of the pesticide residues in manufactured tea, there is an urgent need to explore other avenues for pest management strategies.

Aim: Integrated pest management (IPM) in tea invites an multidisciplinary approach owing to the high pest diversity in the perennial tea plantation system. In this review, we have highlighted current developments of nanotechnology for crop protection and the prospects of nanoparticles (NPs) in plant protection, emphasizing the control of different major pests of tea plantations.

Methods: A literature search was performed using the ScienceDirect, Web of Science, Pubmed, and Google Scholar search engines with the following terms: nanotechnology, nanopesticides, tea, and insect pest. An article search concentrated on developments after 1988.

Results: We have described the impact of various pests in tea production and innovative approaches on the use of various biosynthesized and syntheric nanopesticides against specific insect pest targets. Simultaneously, we have provided support for NP-based technology and their different categories that are currently employed for the management of pests in different agro-ecosystems. Besides the broad categories of active ingredients (Al) of synthetic insecticides, pheromones and natural resource-based molecules have pesticidal activity and can also be used with NPs as a carriers as alternatives to traditional pest control agents. Finally, the merits and demerits of incorporating NP-based nanopesticides are also illustrated.

Conclusions: Nanopesticides for plant protection is an emerging research field, and it offers new methods to design active ingredients amid nanoscale dimensions. Nanopesticide-based formulations have a potential and bright future for the development of more effective and safer pesticide/biopesticides.

Keywords: nanotechnology, tea, insect pest, nano pesticides, IPM 


\section{HIGHLIGHTS}

- Applications of nanoparticles (NPs) in plant protection, emphasizing the control of different major pests of tea plantations

- Categorization of NPs-based technology that is currently employed for management of pests in different agro-ecosystems

- The merits and demerits of incorporating NP-based nanopesticides

\section{INTRODUCTION}

\section{Rationale}

After water, tea leaves (Camellia sinensis) are used to form the most extensively consumed drink on the planet (1). Tea drinking has been shown to have numerous health benefits, including antioxidant, anti-obesity, and anticancer properties. As a result, researchers have paid close attention to tea phytochemicals in terms of structure confirmation, formation mechanism, component clarification, and bioactivity screening of potential constituents (2). Tea is high in bioactives and has been shown to have antiviral properties. Green tea catechins (GTCs) are polyphenolic chemicals found in C. sinensis leaves (3). Green tea drinking has been linked to a reduction in the risk of carcinogenesis in a variety of cancers, including prostate cancer (4). Black tea constituents theaflavin 3,3'-digallate, theaflavin 3-gallate, and procyanidin B2 have the potential to serve as inhibitors for SARS-CoV-2 targets and could be used as therapeutic candidates in future investigations against COVID19 (5). As a result, the safety and quality of raw tea leaves are critical indicators in the production of tea and related products (1). However, the tea plantations provide a stable microclimate and food supply for several notorious pests such as insects, mites and nematodes, etc., (Table 1 and Figure 1) due to the perennial and monoculture nature of tea plant cultivation, which causes substantial crop loss annually. However, geographical variation in pest diversity exists due to the effect of climate change, altitude, the age of the plantation, etc.

Even though there are numerous non-conventional methods available, pest control in the tea ecosystem is based on the use of synthetic pesticides. Although ATP (adenosine triphosphate) disruptors of IGR (insect growth regulators) have been introduced recently for insect pest management, neurotoxic pesticides (mode of action that interferes the nervous system of insects) are still in use for the management of insect pests, which poses a risk to mammals and non-target organisms besides having an environmental impact (10). In addition to this bioaccumulation, environmental contamination, and mammalian toxicity, continuous application of these pesticide compounds accounts for major key challenges in agriculture due to resistance development in insect pests. Therefore, novel and innovative strategies using advanced technologies are essential to address those problems. Nanotechnology, a promising and emerging research field, could help towards attaining these goals for crop protection as it offers new methods for designing novel AIs using existing pesticides with nanoscale dimensions (below
$1,000 \mathrm{~nm}$ ) along with the target-specific delivery of the nanoemulsions, dispersion, and formulation, and these can be referred to as nanopesticides (11-13). Nanopesticides are expected to deal with the limitations of existing strategies to control insect pests and provide newer and advanced formulations that can penetrate the insect body, remain active and stable in the target ecosystem and be benign to the non-target organism, be cost-effective, and minimize defense of the target pests $(11,14,15)$.

\section{Objectives}

The aim of this article was to look at how nanotechnology is being used in crop protection now and in the future. It examined nanoscientific developments of potential nanoparticles (NPs) for agricultural pest control with a focus on the control of various major insect pests of tea plantations using nanoparticlebased pesticide delivery systems, polymer nanocarriers, inorganic nanocarriers, mineral-based nanoparticles, and Nano biopesticides. We have also conducted a brief review of the literature on nanoscientific advances in nanotechnology, nanopesticides, and integrated insect pest management in tea plantations.

\section{METHODS}

A comprehensive literature search was conducted using Web of Science, ScienceDirect Pubmed, Google Scholar, and other online sources. The article search focused on nanotechnology, nanopesticides, tea, and insect pests in the domain of "Agricultural and Biological Sciences" in the subdomains of Agricultural and Biological Sciences (general) and Agronomy and Crop Sciences." Original articles from 1988 onwards were of great interest. The research experience of the authors as well as information gleaned through personal communication are also included.

\section{RESULTS AND DISCUSSION}

\section{Results of the Literature Search and Selection}

A total of 312 non-duplicate publications were obtained from the four databases, with 62 articles being eliminated after the Title/Abstract Screen. In total, 250 papers were obtained for full-text evaluation after 62 duplicates were removed and title/abstract screening was performed. Following a review of these full-text publications, 46 articles were found to be excluded after Full-Text Screening and 31 articles were found to be Excluded During Data Extraction. Finally, the analysis comprised 173 publications on Nanotechnology, tea, insect pests, and nanopesticides. Figure 2 depicts the screening and selection method.

\section{Impact of Pests on Tea Production}

Tea, as a perennial mono-crop cultivated in favorable climatic conditions, has become conducive for a large number of insects and mite pests, disease, and weeds as a food source, and this needs to be managed to avoid huge crop losses. More than 1,030 species of arthropods are linked to the tea ecosystem throughout the world, and due to various pests, the entire tea industry has seen a 
TABLE 1 | Different pests of tea crop [source: Deka et al. (6, 7); Babu (8); Hazarika et al. (9)].

\begin{tabular}{|c|c|}
\hline Common name & Scientific name \\
\hline \multicolumn{2}{|l|}{ Major pests of tea } \\
\hline Tea mosquito bug: & Helopeltis theivora Waterhouse (Miridae: Hemiptera) \\
\hline Thrips & Scirtothrips dorsalis Hood (Thripidae: Thysanoptera) \\
\hline Jassid & Empoasca flavescens Fab. (Cicadellidae: Hemiptera) \\
\hline Aphids & Toxoptera aurantii Boyer de Fonscolombe (Aphididae: Hemiptera) \\
\hline Bunch caterpillar: & Andraca bipunctata Walker (Bombycidae: Lepidoptera) \\
\hline Red spider mite & Oligonychus coffeae Nietner (Tetranychidae: Acari) \\
\hline Tea looper complex & Buzura suppressaria Guen (Geometridae: Lepidoptera), Hyposidra talaca (Walker), H. infixaria (Walker) (Geometridae: Lepidoptera) \\
\hline Shot hole borer & Euwallacea fornicates Eichhoff (Scolytidae: Coleoptera) \\
\hline Live wood eating termite & Microtermes obesi (Isoptera:Termitidae) \\
\hline Scavenging termites & Odontotermes obesus (Isoptera:Termitidae) \\
\hline \multicolumn{2}{|l|}{ Minor pests of tea } \\
\hline Flush worm & Cydia leucostoma Meyrick (Tortricidae: Lepidoptera) \\
\hline Pink and Purple mite & Acaphylla theae Watt and Calacarus carinatus Green (Eriophyidae: Acarina) \\
\hline Scarlet mite & Brevipalpus phoenicis Geijskes (Tenuipalpidae:Acarina) \\
\hline Yellow mite & Polyphagotarsonemus latus Banks (Tarsonemidae: Acarina) \\
\hline Leaf roller & Caloptilia theivora Walsingham (Gracillariidae: Lepidoptera) \\
\hline Scales & Saissetia formicarii Takahashi S. coffeae Walker, Eriochiton theae Green, Coccus viridis Green (Coccidae: Hemiptera) \\
\hline Tea tortrix & Homona coffearia Nietner (Tortricide: Lepidoptera) \\
\hline
\end{tabular}

crop loss of $20-35 \%$ despite using plant protection formulations. From root to tender shoots, all parts of the tea bush are attacked by various pest species (9).

To take appropriate control measures, the economic threshold level (ETL) is considered as one of the crucial requirements, and it indicates the density of population at which different control measures for the management of pests should be adopted to avert increasing pest population from touching the economic injury level (EIL) (Figure 3 and Table 2). In tea plantations, the EIL is very high for those pests that infest the new shoots as their damage directly affects the yield, and in cases for the pests that infest the other parts of the tea bush, the immediate EIL is low, but their damage affects the growth of the new shoots as well as the health of the bush (17).

\section{Management of Tea Pests in Conventional Methods}

Based on the ecological characteristics of tea fields and the cropping system of tea, a tentative IPM system comprising all possible control methods has been proposed (Figure 4) $(6,8$, 17).

\section{Biological Control}

The three common approaches followed for biological control of tea pests include classical, conservation, and augmentative biological control. More than 170 species of parasites, entomopathogens (entomopathogenic fungi, entomopathogenic nematodes, viruses, and bacteria), predators (coccinellids, syrphids, mirids, phytoseiids, and spiders), parasitoids (braconids, bethylids, eulophids, ichneumonids, tachinids, and muscids), and hyperparasites are reported from typical monoculture tea ecosystems, which are extremely efficient at regulating several insect pests $(7,18-21)$.

Microorganisms belonging to fungi like Metarhizium anisopliae, Verticillium lecanii, Steinernema sp., Beauveria bassiana, and Paecilomyces fumosoroseus along with baculoviruses viz., nuclear polyhedrosis virus (NPV), granulosis virus $(\mathrm{GV})$, etc. occur naturally and are identified and formulated into microbial pesticides by following appropriate techniques for production, standardization, formulation, and application. This has progressed well in India, Japan, Sri Lanka, and China to control the tea pests (22-26). In the cultivation of organic tea, botanicals having pesticidal properties play an important role. Hundreds of botanicals, which are having significant oviposition deterrence or antifeedant or toxic effects, have been reported $(6,27,28)$.

\section{Chemical Control}

Insecticides are one of the key strategies to control the tea pests, which includes synthetic pyrethroids, neonicotinoids, spinosyns, avermectins, pyrazoles, and oxidizes $(29,30)$.

Besides the biological and chemical approaches, several other approaches have been followed for integrated pest management in tea plantations. Cultural practices include pruning and plucking operations, field sanitation and crop refuse destruction, tillage of soils, soil amendments, and fertilizers, trap crops and shade trees, water management, and adopting various mechanical and physical methods viz., hand collection and destruction, use of physical or chemical barriers, light traps, attractants, repellents, etc. 


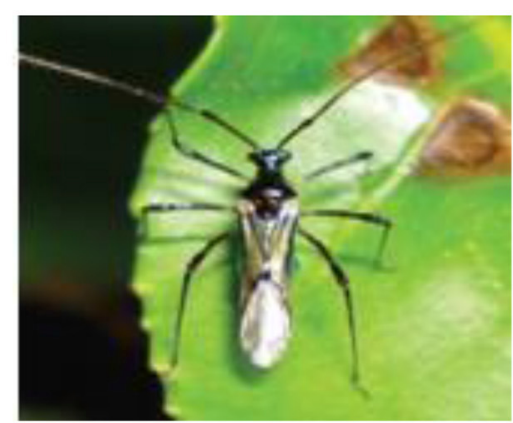

H. theivora

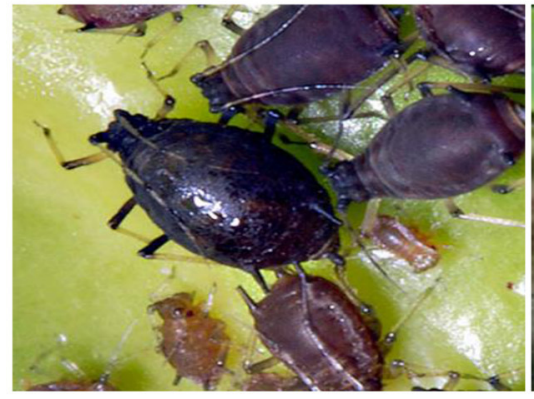

T. aurantii

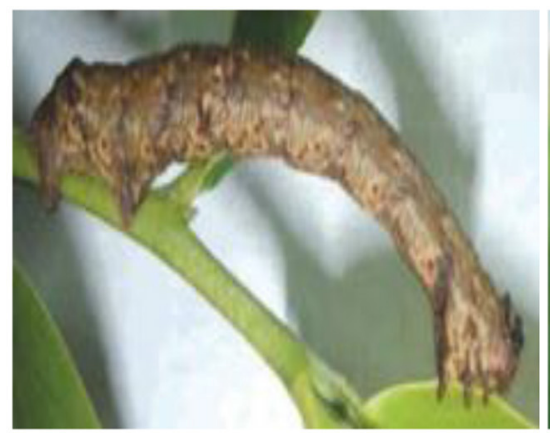

B. suppressaria

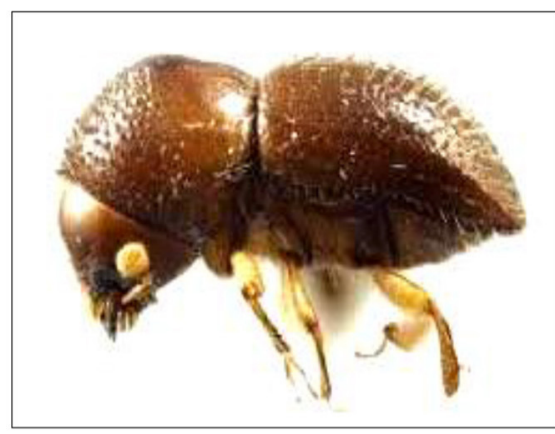

E. fornicates

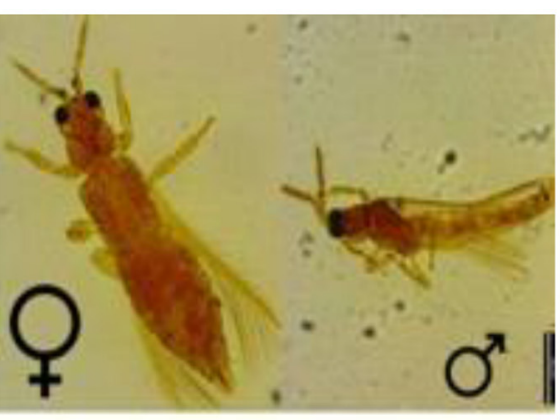

S. dorsalis

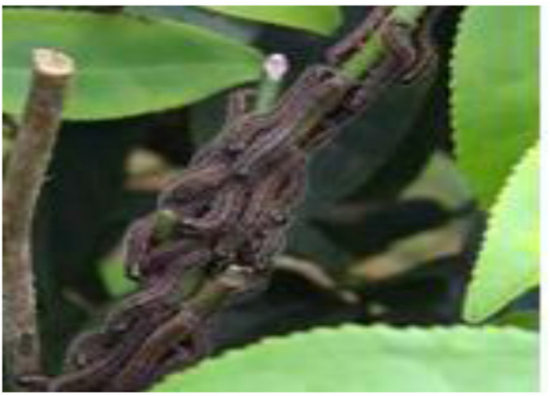

A. bipunctata

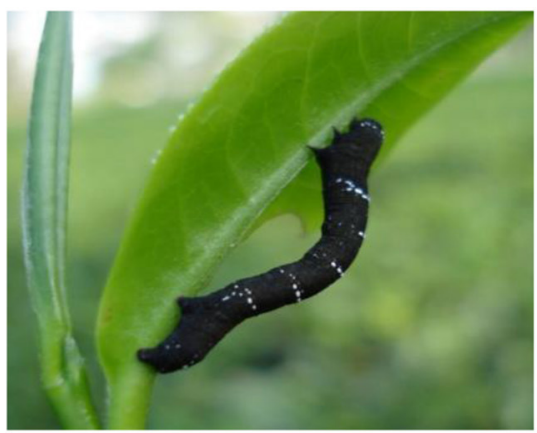

H. talaca

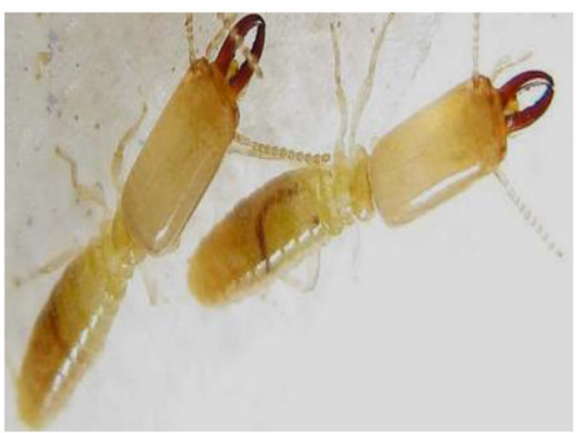

M. obesi

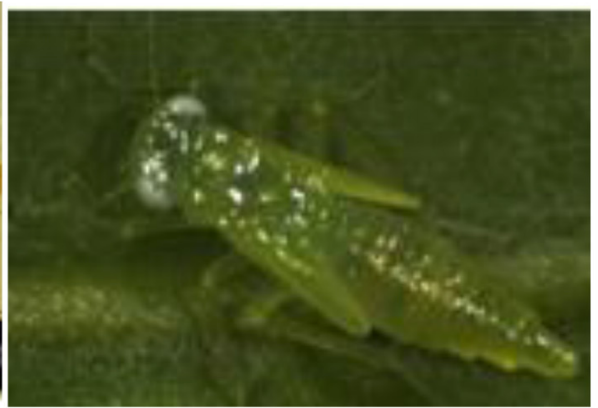

E. flavescens

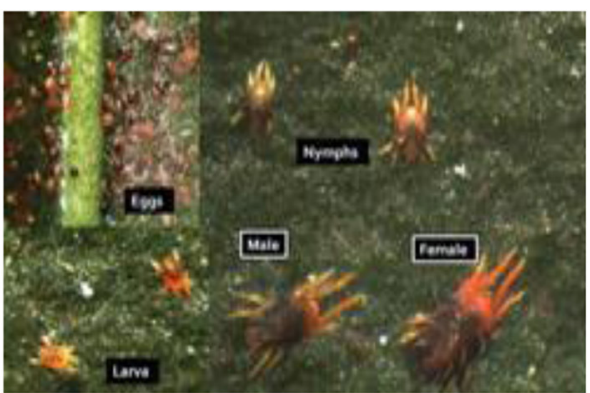

O. coffeae

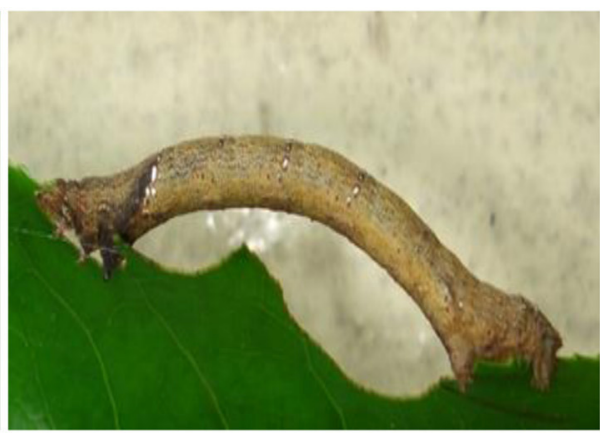

H. infixaria

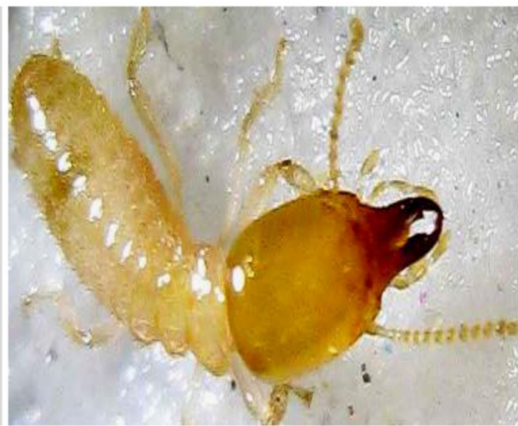

O. obesus

FIGURE 1 | Major pests of tea crop. 


\section{Identification of studies via databases and registers}

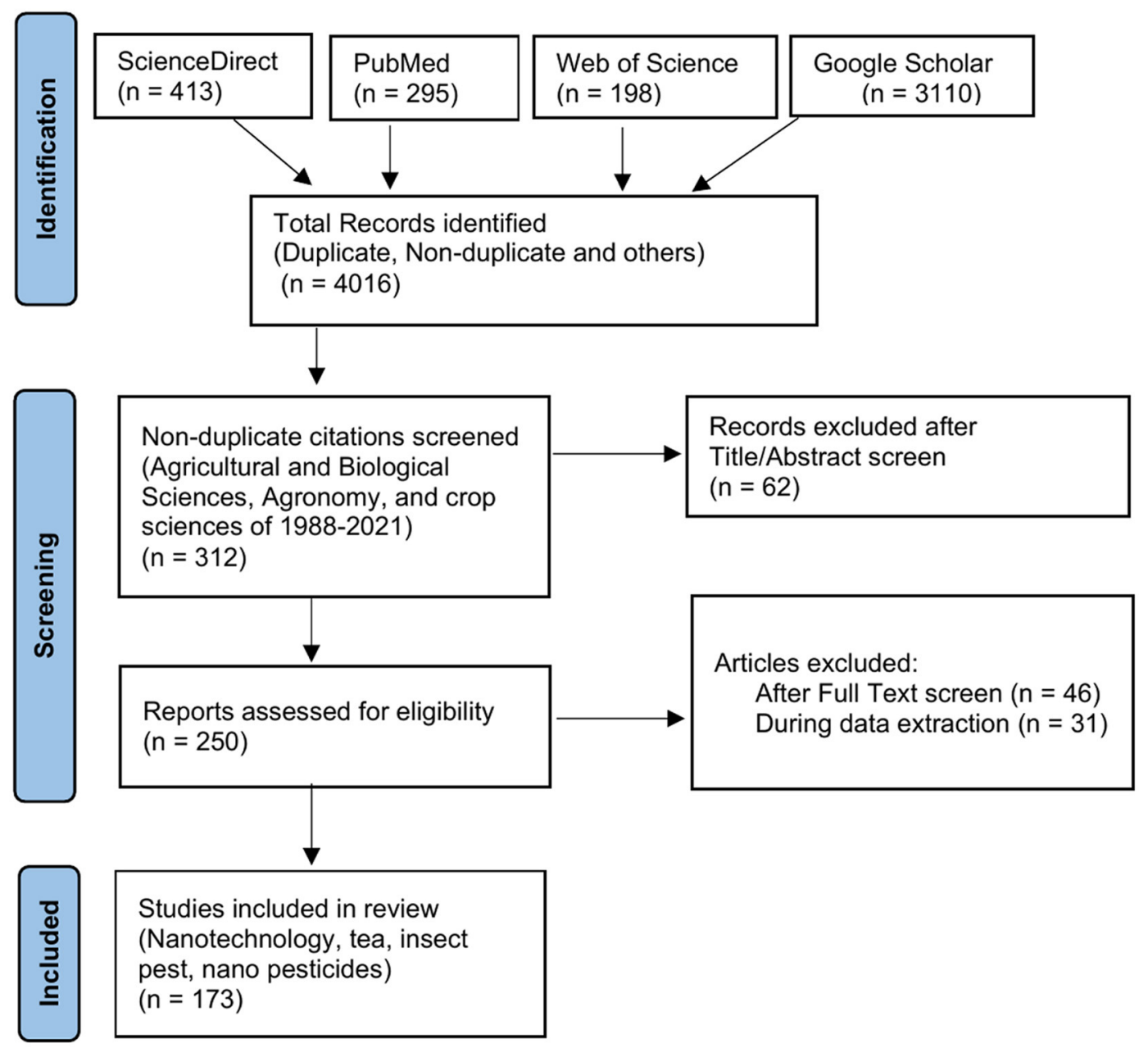

FIGURE 2 | The flowchart of the literature search, screening and selection.

\section{Why Use Nanopesticides for Insect Pest Management in Tea Crop?}

Nanopesticides refer to the utilization of nanotechnology for plant protection, an emerging research field, offers new methods to design active ingredients amid nanoscale dimensions, in addition to their formulation and delivery. This field comprises broad research aspects including the study of basic understanding of the interface between insects and nanoscale materials, formulation of AI into nano-emulsions and dispersions with accessible pesticides, preparation of new nano-pesticide using nanomaterials as active pesticide agents or nanocarriers for their delivery (11-13). Extensive research on nanopesticides is expected to deal with the restrictions of the accessible strategies used for pest control and endowed with nanobased novel formulations that enter into the target (pest), remain steady and active in the environment, without impact on non-target organisms, using cost-effective formulation $(11,15)$.

Auffan et al. (31) defined nanoparticle (NP) as ultrafine particles comprising dimensions from 1 to $100 \mathrm{~nm}$ in size and have characteristics that are not shared by non-nano scale particles with a similar chemical composition. The key parameters for the NP for use as nanopesticides include some specific properties viz., chemical composition (organic, inorganic, metallic, polymeric, and carbon), shape (rods, spherical, irregular, and tube), the surface to volume ratio, size, and crystal phase (amorphous and crystalline) besides the toxicity. NP-based pesticides tend to show several benefits in comparison to conventional pesticides viz. increased solubility in water and the stability of the formulation, its ability to eliminate toxic organic solvents and release the $\mathrm{AI}$ at a slower rate, its enhanced mobility, and its insecticidal activity (32). Recent 


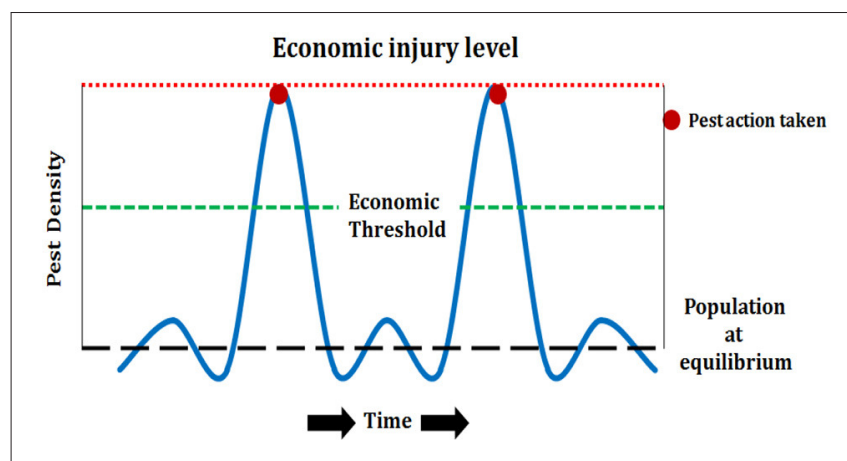

FIGURE 3 | Economic injury level (EIL) and Economic Threshold Level (ETL) of tea pests.

TABLE 2 | Economic Threshold Level (ETL) of major pests of tea (16).

\begin{tabular}{ll}
\hline Name of the pest & Economic threshold level (ETL) \\
\hline Tea Mosquito Bug & $5 \%$ infestation \\
Aphids & $20 \%$ infestation \\
Thrips & 3 Thrips per shoot \\
Jassids & 5 jassids per shoot \\
Looper caterpillar & $4-5$ Lopper per plant \\
Flushworm, Leaf Rollers & 5 infested rolls per bush \\
Red Spider Mites, Pink and Purple Mites & 4 mites per leaf \\
Termites & $10 \%$ infestation \\
Nematodes & 6 numbers of nematode/10 gm of soil
\end{tabular}

studies indicated that to formulate NP, varieties of materials were synthesized in various forms of chemical compositions including carbon, silicates, polymers, metal oxides, lipids, semiconductor quantum dots, ceramics, emulsions, proteins, and dendrimers (33-35).

\section{NPs to Improve Pesticide Formulations to Control Insect Pest}

Recent studies also showed different plant-synthesized NPs and their efficacy against a wide range of economically important insect pests, including mosquitoes (15), beetles (36), moths (37), hard ticks (38), lice (39), louse flies (40), etc. Hence, most of the formulation of pesticides are available in oilin-water $(\mathrm{O} / \mathrm{W})$ emulsions or emulsifiable concentrates (ECs) and are sparingly water-soluble (41). Usually, EC formulations contain very expensive organic solvents that are more toxic and flammable or a mixture of surfactant emulsifiers. On the other hand, the $\mathrm{O} / \mathrm{W}$ emulsions are based on a blend of nonionic and polymeric surfactants, which requires high-energy input for emulsification $(42,43)$. To address the disadvantages of these conventional pesticides, new formulations are being introduced based on micro and nanoemulsions (41, 44-47). For the management of a wide range of pests and diseases in different agroecosystems, several formulations based on microemulsion are available, including systemic fungicides and plant growth regulators $(46,48,49)$. Micro-emulsions are steadier than the nano-emulsions (nano-emulsions require high energy input for scale-up for commercial production and are difficult for onsite production by the handlers) and advantageous over the conventional formulations (they have improved stability and tank mix compatibility, reduce toxicity to the handler and flammability, and have increased efficacy due to better uptake and penetration from surfactants having high solubilizing power) (41, 50). Conversely, micro-emulsions showed various disadvantages viz., higher surfactant concentrations, with very low AI contents and the limited number of suitable surfactants (45). These limitations could be partly sorted out by different formulation concepts based on nano-suspension or nano-dispersion, where AI of nanocrystals creates nano-dispersions containing similar properties of solutions, and the development of such suitable release systems could enhance the pesticide's efficiency and performance, reducing adverse environmental effects (51). In general, NPs are customized to carry a specific biomolecule to the organ, tissue, or even cell, and using a nanocarrier can easily penetrate the insect or plant cell and accurately deliver the products (52). For delivery and tracking purposes, various inorganic nanomaterials with distinctive chemical and physical properties, viz., silica, metal oxides, metals, semiconductors, and carbon-based materials, have been prepared (53). In addition to protecting crop plants from pests and diseases, nano-delivery vehicles can enhance plant growth, yield, seed vigor, and could even be used for manipulation of genes (54). By creating new pores either through ion channels or by binding to a carrier protein, the NPs enter into the plant cells and can cause significant changes to these systems (55). Despite the remarkable capability of the plant cell wall during the entry of NPs (12, 56), some unlikely impact of NP application has been raised, and studies are being continued focusing on phytotoxic effects of NPs $(57,58)$ and their influence on plant development $(59,60)$. Electron microscopic studies of the effect of NPs on insects and plants also revealed that they can penetrate the cell, mitochondria, or nucleus of insects and plant easily, and this suggests that NPs can be used as a pesticide for target delivery $(12,56)$.

\section{Pesticide Delivery System Using Nanoparticles as Nanocarriers}

The concept "pesticide delivery system" (PDS) was developed based on the drug delivery concept used in medicine where NPs are used to deliver the therapeutics to the target organs (61). PDS is designed to make available of the AI to a specific target at specified durations and concentrations to achieve the projected biological efficacy and by minimizing the harmful effects on non-target organisms (62). For the optimized release of sufficient and necessary amounts of pesticides within a specific time, controlled delivery plays an important role (61). Possession of specific characteristics of NPs, viz., high effective loading capacity, larger surface area, fast mass transfer to the insect's body (target), and the ability for easy attachment of various pesticide molecules, encouraged the use of NPs as nanocarriers. Pesticide molecules after encapsulations, show more gradual release over time, hence it requires fewer applications; at the same time, due to degradation, NPs hinder the loss ineffectiveness of the pesticides. 


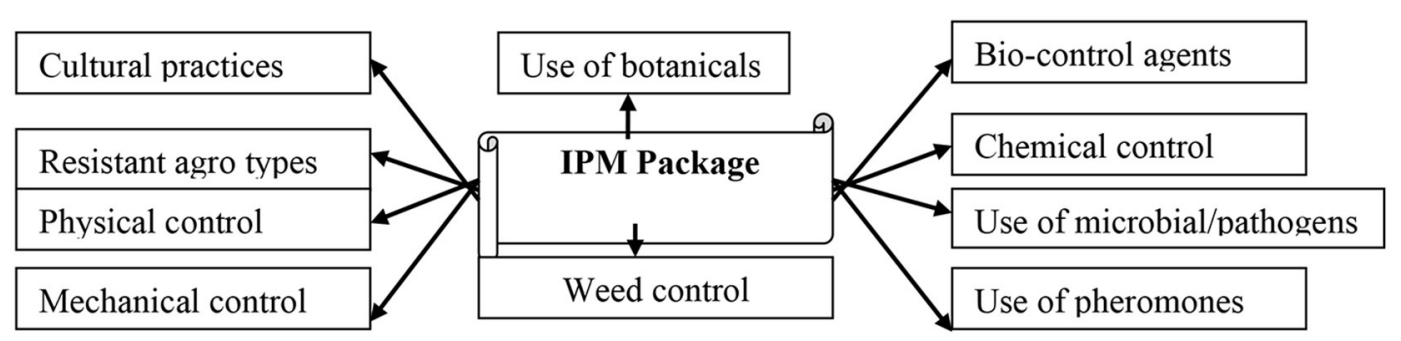

FIGURE 4 | IPM components for tea pests.

For loading of pesticide molecules on NPs, different concepts, viz., encapsulation, adsorption, entrapment inside the NP, and covalent attachment reconciled by various ligands, are adopted (10) (Figure 5).

Based on the bonding of the AI to the material, degradation properties of the nanocarrier, and the environmental conditions, control and slow-release characteristics of the molecules could be attained. For the delivery of pesticides, nanocarriers like synthetic silica, polymer, titania, silver, alumina, and copper are mostly used. A few common examples of insecticides prepared using nanotechnology are listed in Tables 3, 4. Utilization of nanoencapsulation technique indicates safer usage of pesticides and less exposure to the ecosystem. Among all the NPs available, the solid and mesoporous silica NPs have shown the most potential delivery agent of agrochemicals due to their structural flexibilities for the formation of NPs of different shapes and sizes and ability to form pores during loading the biomolecules $(58,108-111)$.

\section{Polymer Nanoparticles as Nanocarriers}

Polymer NPs that include polymeric nanocapsules and nanospheres are being used as polymer nanocarriers due to their flexibility to design a complex pesticide delivery system with various modes of actions, biocompatibility, scalable preparation, and biodegradation. In polymer nanospheres, the AIs of pesticide molecules (hydrophobic molecules) are randomly distributed with a core-shell structure in a polymer matrix in nanocapsules (known as polymer micelles), and this acts as a reservoir for encapsulation (112). Polymer nanocapsules provide advantages over larger capsules due to their improved uptake, the stability of the spraying solution, the spraying surface, and the homogenous distribution, which provides better knockdown of pests. As essential oils and secondary metabolites (phytochemicals) display stability problems (rapid evaporation and degradation of AI in presence of high temperature, moisture, and air) during the application, polymer nanocarriers can play a protective function and can increase their cost-effectiveness by maintaining the minimum effective dosage (62). For designing polymer formulations, different types of polymers, viz., polysaccharides (chitosan, starch, and alginates), polyesters [PEC (poly-e-caprolactone) and PEG (polyethylene glycol)], and biologically originated biodegradable materials (beeswax, cashew gum, lecithin, and corn oil) have been evaluated $(113,114)$. Among all of these polymers, PEG-based amphiphilic copolymers show better biodegradability, which is also easy for processing $(112,115)$. PEG polymer nanoformulation-based pesticides showed significantly slower release of the AIs in comparison to chemical pesticides like thiamethoxam (116), imidacloprid (117), beta-cyfluthrin (118), and carbofuran (119) and better efficacy than the chemical pesticides for control of nematodes $(119,120)$.

\section{Inorganic Nanoparticles as Nanocarriers}

During the last two decades, for the formulation of pharmaceuticals, solid inorganic NPs are being used due to their various advantages viz., nanoemulsions, polymer NPs, better stability, higher loading, more controlled release, and low-cost production. Similarly, the solid inorganic NPs are used nowadays in agrochemical industries for the development of advanced pesticide delivery systems (14, 42, 62, 121-126). Among all the inorganic NPs, silica NPs are used mostly as nanocarriers for efficient delivery of biopesticides, insecticides, pheromones, and fungicides $(49,85)$. Silicon enhances the plant tolerance to different biotic and abiotic stress, and silica NPs are thus a potential candidate for use in pesticides for controlling agricultural pests (85), including tea pests. Pesticidal formulations based on silica NPs showed slow release of chlorfenapyr and promising results as an insecticide $(127,128)$. Under field conditions, the insecticidal activity of chlorfenapyr associated with silica NPs was found to be two times higher than the chlorfenapyr without NPs (128). To control insect pests during grain storage and field conditions, the prospective use of nano-silica has been reported against many pests (129-133).

\section{Using NPs Alone as Pesticides}

NPs with insecticidal properties can be used not only as nanocarriers but also as biopesticides or active agents for pesticides $(85,134)$. The amorphous nano silica acquired from the shell wall of phytoplankton, vegetables, rice hulls, and volcanic soil is the most promising example of NPs with insecticidal properties $(85,135,136)$. Similar to the mode of action of diatom particles (used for stored grain protection), the silica NPs can disrupt the protective barrier of insects and finally lead to the death of the same $(85,135,137,138)$. Earlier studies reported that the application of silica NPs in adult rice weevils, Sitophilus oryzae, caused 100\% mortality (129). Similarly, a wide range of insect pests in agricultural and 


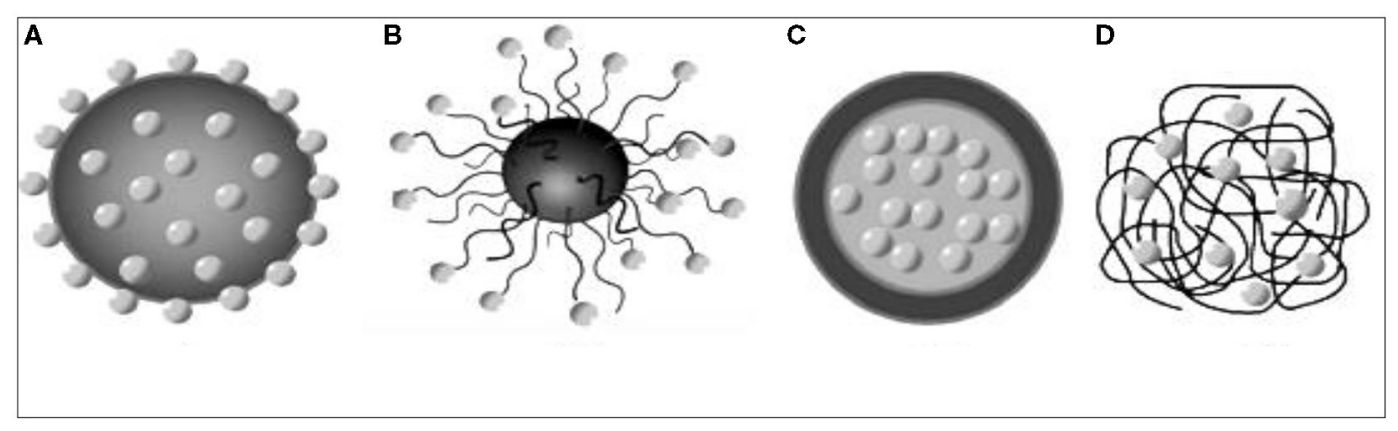

FIGURE 5 | Schematic representation of NPs for delivery of pesticides, (A) adsorption on NP, (B) attachment on NP by different linkers; (C) encapsulation inside polymeric hydrophobic or hydrophilic core (polymer micelles); and (D) entrapment inside polymeric nanoparticle [source: Athanassiou et al. (10)].

TABLE 3 | List of various encapsulated nanopesticides used against insect pest management.

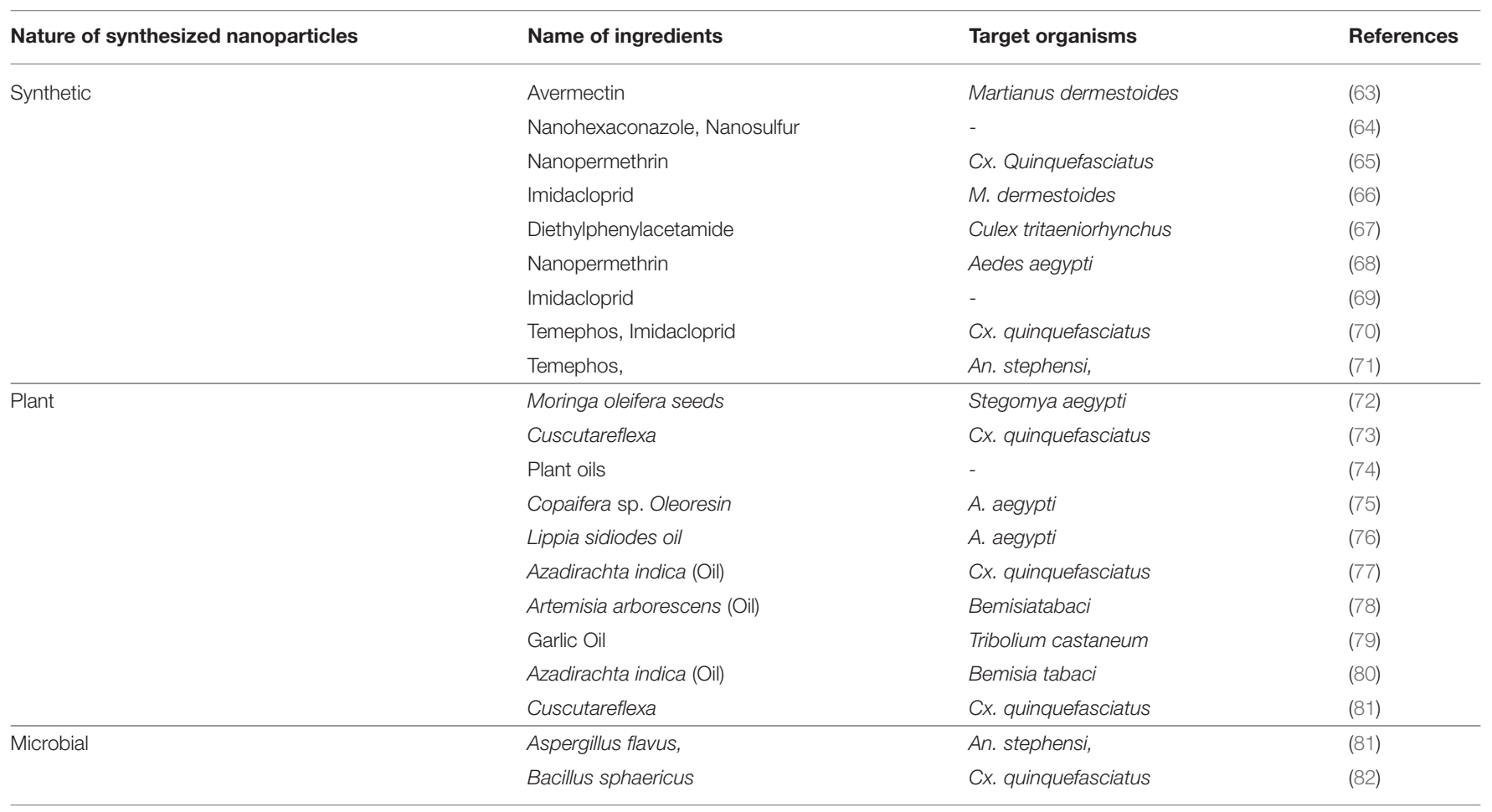

animal ectoparasites was successfully controlled using surfacecharged modified hydrophobic silica NPs (139). The application of silica NPs as a thin film on seeds showed a reduction of fungal growth; on the other hand, it boosted germination (140). World Health Organization (WHO) considered safe for humans in the exploitation of silica NPs as a nano-bio-pesticide (138). Hence, silica NPs could be used as a pesticide for the control of agricultural and household pests, parasites, and fungi.

\section{Silver and Other Mineral-Based Nanoparticles}

Similar tothe other nanomaterials, the metal-based NPs can be combined with pesticide molecules, which increases the effectiveness of the pesticide formulation (141-143) and reduces the application dose (144) for management of tea pests. These NPs can be synthesized solely using chemical compounds or involving living organisms (145). NPs based on silver, nanostructured alumina, aluminum oxide, zinc oxide, and titanium oxide have shown insecticidal properties. The larvae of case-bearing cloth moths, Tinea pellionella, showed $100 \%$ mortality while treated with ethanol-based nanosilver colloid ( $<20 \mathrm{ppm})$ (146). The wettable dust formulation of nanostructured alumina showed more than $95 \%$ mortality of $S$. oryzae and $R$. dominica adults infesting wheat within 3 days of exposure (87). Moreover, by combustion of aluminum nitrate and glycine, the prepared nanostructured alumina at $60 \mathrm{ppm}$ dose showed more than $94 \%$ mortality for S. oryzae adults when applied as dust on wheat (147). Buteler et al. (148) obtained similar results for control of $S$. oryzae and $R$. dominica in wheat 
TABLE 4 | List of various non-encapsulated nanopesticides used against insect pest management.

\begin{tabular}{|c|c|c|c|}
\hline Nature of synthesized nanoparticles & Name of ingredients & Target organisms & References \\
\hline \multirow[t]{4}{*}{ Synthetic } & Silver and Gold nanoparticles & Aphis nerii & (83) \\
\hline & $\begin{array}{l}\text { Silver, Aluminum Oxide, Zinc } \\
\text { Oxide and Titanium dioxide } \\
\text { Nanoparticles }\end{array}$ & insect pests and pathogens & (84) \\
\hline & Nanosilica & An. stephensi, Cx. quinquefasciatus A. aegypti & $(85,86)$ \\
\hline & Nanoalumina & Sitophilus oryzae (L.), Rhyzopertha dominica (F.) & $(87)$ \\
\hline \multirow[t]{6}{*}{ Plant } & Nelumbo nucifera & Anopheles stephensi, Cx. quinquefasciatus & (88) \\
\hline & Aloe vera & Anopheles stephensi & (89) \\
\hline & Mukia maderaspatana & Cx. quinquefasciatus, $A$. aegypti & (90) \\
\hline & Plumeria rubra & A. aegypti A. stephensi & $(91)$ \\
\hline & $\begin{array}{l}\text { Jatropha gossypifolia, Euphorbia } \\
\text { tirucalli, Pedilanthus } \\
\text { tithymaloides, Alstonia } \\
\text { macrophylla }\end{array}$ & A. aegypti & $(92)$ \\
\hline & Emblica officinalis & - & (93) \\
\hline \multirow[t]{13}{*}{ Microbial } & Aspergillus & - & (94) \\
\hline & Aspergillus & - & (95) \\
\hline & Aspergillus & & $(96)$ \\
\hline & Phytopthora infestans & - & $(97)$ \\
\hline & Aspergillus & - & (98) \\
\hline & Aspergillus & - & (99) \\
\hline & Trichoderma reesei & - & $(100)$ \\
\hline & Chrysosporium tropicum & Anopheles stephensi Cx. quinquefasciatus & $(101)$ \\
\hline & Epicoccum nigrum & Pathogenic fungi & $(102)$ \\
\hline & Aspergillus & - & $(103)$ \\
\hline & Rhizopus & - & $(104,105)$ \\
\hline & Aspergillus niger & An. stephensi, Cx. quinquefasciatus, A. aegypti & $(106)$ \\
\hline & Schizophyllum & - & $(107)$ \\
\hline
\end{tabular}

when novel nanostructured alumina was prepared based on chemical solution method and applied as dust. Buteler et al. (148) while studying the mode of action of the nanostructured alumina dust, reported that, through capillarity mechanism, the epicuticular lipids absorb the dust, which leads to dehydration of the insect and finally causes death. However, the effectiveness of the metal-based NPs depends on their physical properties, (viz., morphology, size, and surface area of the particle), biotic factors (viz., target species, exposure interval, and dose), and abiotic factors (relative humidity) $(147,148)$.

\section{Nano Bio-Pesticides}

The selection of nano bio-pesticides have various important points for consideration, viz., they should be easy to prepare, economically viable, effective against a wide range of pests, must be safer to non-target organisms as well as the environment, non-toxic, should not accumulate in the food chain, should have nil or negligible residues, should not affect the quality of food, fragrance, texture, and flavor, and should be easy availability for application (149). Generally, for improvement of efficacy, better solubility, a slower rate of release and degradation, the traditional methods for the preparation of synthetic pesticides are blended (150). Similarly, for the formation of nano bio-pesticides, the biological compounds having pesticidal properties serve as capping and reducing agents and are blended with silver salt (149). Biologically synthesized NPs differ from chemically synthesized NPs in terms of their activities and effects on insect pests and plants. Due to the large surface area present in NPs, they can bond other compounds quickly and can circulate easily in the lepidopteran insect's system (85). Studies reported that nanocarrier materials with plant secondary metabolites cause indigestion, collapse the water protection barrier ultimately resulting in the death of insects (150). The nanosize of the compounds facilitates effectiveness with us a minimal quantity of bio-pesticides, protect the active secondary metabolites besides supporting the controlled release of the compound (150). The combination of a certain plant extract with nano-silica significantly increased the insecticidal activity as well as the shelf life (151). Most of the terpene compounds are reported to have antifeedant activity. Nanoformulation prepared using terpene compounds (alpha-pinene and linalool) by combining with nano-silica not only increases the efficacy (antifeedant activity against $S$. litura and A. Janata) but also enhances shelf life by more than 6 months $(151,152)$. Against tea pests, the nano bio-pesticides can be used both directly and indirectly as vectors as they can inherit some of the essential properties viz., permeability, stiffness, crystallinity, biodegradability, and thermal stability, 
and these properties are advantageous over commonly used synthetic pesticides. When AgNPs biosynthesized from the medicinal plant Piper betle leaf extract are tested against Daphnia magna for ecotoxicological studies, they showed less toxicity when compared to the chemically synthesized AgNPs, which confirmed the fact that biologically synthesized AgNPs are safer (because of the formation of the protein core around the NPs during synthesis) than the chemically synthesized AgNPs (153). Similar eco-friendly characteristics were reported with platinum $(\mathrm{Pt})$ - and palladium (Pd)-biosynthesized NPs using $P$. betle leaf extract (154).

\section{Advantages of the Use of Nano-Pesticides Over Conventional Pesticides}

To develop novel eco-friendly formulations for pest control, nanotechnology offers a tool for target-specific nanopesticides. Usually, target-specific nanopesticides could improve the effectiveness of pesticides and reduce pollution and undesirable residues in tea. They have slow release and protection performance as nanopesticides are prepared using thermosensitive, light-sensitive, humidity-sensitive, soil $\mathrm{pH}$-sensitive, and enzyme-sensitive high polymer materials to deliver the pesticides. On plant surfaces, these formulations improve the adhesion of droplets, conferring improvement of dispersion and bioactivity of AI of target pesticide molecules. For these reasons, compared to conventional pesticides, nanopesticides show better efficacy for the management of tea pests. Nanopestides offer competent and eco-friendly advantages because of their small sizes, their efficacy when spraying in the field improvement of droplet adhesion on the plant surface, their wettability, as well as their rapid absorption by the target. It reduces the quantity of chemical usage, enhances plant protection, and reduces the toxic residues; hence nanopesticides enable the sustainable production of tea (155).

\section{Types of Nanopesticides}

Nanopesticides play a major role in minimizing the footprints left by synthetic pesticides in agroecosystems. Encapsulated nanopesticides (Table 1) and several other nano-forms of silica, silver, iron, copper, and carbon (Table 2) are already in the practice of insect pest management.

\section{Potential of Nano-Pesticides for Agricultural Pest Control}

Metabolites (terpenoids, flavonoids, and alkaloids) are plantderived products (PDP) that consist of a complex mixture of compounds that act in diverse ways on insects, such as repellents, antifeedants, insect growth regulators, oviposition deterrents, and in terms of toxicity, and their mechanisms of actions are diverse (156). Most of the findings on the botanicals or PDP are restricted to the laboratory and have not been validated at field conditions (157). Indeed, marginal and small farmers in developing countries have introduced and regularly using the locally available plant products (water extract, crude oils, or seed cakes, etc) and commercial formulations [emulsifiable concentrations, wettable granules, solvent-based products, active ingredient (AI)] (156). These PDPs are established as effective commercial formulations (158). The presence of $\mathrm{AI}$ and allelochemicals in essential oils (EO) shows better efficacy than the PDP extracts (159). As a result of the quick "knockdown effect" on insect life stages and the accessibility of ready-made formulations, farmers use chemical pesticides in agriculture, but in most cases, these pesticides do not reach the target insect and are lost in the air, leached out in soil and water $(62,160)$. Besides, overuse or misuse of doses without following proper recommended mixtures and repeated applications of chemicals pesticides lead to several issues viz., development of insect resistance and undesirable residues in commodities and can harm humans and non-target organisms as well as the environment. Exposure to sunlight would lead to quick degradation of PDP and leave less persistence in the environment, have less of an impact on non-target organisms, and shows less residue (156). In comparison to the conventional chemical pesticides, the better properties in PDP nanotechnology are endorsed to controlled systems discharging small-sized molecules at the place of action, decreasing the residual problem, maximizing the action of the AI, increasing the target specificity, and increasing both the physicochemical stability and effectiveness of AI $(62,161)$. Nanopesticides are recognized to have less of an impact on human health and the environment and display less toxicity to non-target organisms as well as animals (161).

\section{Current Issues and Challenges Bio-Efficacy}

With the limited bioavailability of nanocarriers, both nanocarriers and AI need to be endowed with a requisite amount for attaining the preferred level of tea pest control. Hence, the durability and bioavailability of these components in PDPbased nanopesticides should be established (43). Commercial products, specifically the powder formulations confirmed better UV stability than the encapsulated nanoformulations (162). In practice, liquid formulations are preferred by the farmers. Hence, escalating persistence and stability in solid formulations is a challenge to the manufacturers. For this, Vrignaud et al. (163) suggested encapsulation of hydrophilic molecules in polymer-based nanoparticles and assessment of risks to nontarget organisms with increasing uptake of AI to enhance the bio-efficacy of the same.

\section{Toxicity to Plants}

Azadirachtins in nanoformulation cause genotoxic and cytotoxic effects in plants, but during plant development, the toxicity is reduced to an undetectable level under sunlight (164). In another case, Liu and Xing (165) discussed different types of nanomaterials (nanotubes, $\mathrm{Al}, \mathrm{ZnO}, \mathrm{Zn}$, and multi-walled carbon) that did not show any adverse effect on five different vegetables and ryegrass during seed germination and termination of root elongation. For corn plants treated with oleic acid and nanocapsules separately, Psquoto-Stgliiani (161) observed a negative effect on the physiological parameters against oleic acid, while there was no phytotoxic effect for nanocapsules.

\section{Toxicity to Non-target Organisms in Agro-Ecosystem}

Neem oil nanoformulation showed less toxicity to parasitoids of whitefly Bemisia tabaci and a parasitic wasp, Encarsia formosa when neem oil was added on polymeric nanocarriers 


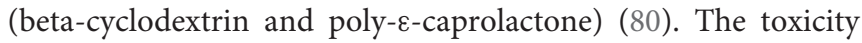
of plant-derived metallic nanoparticles on microorganisms and earthworms depends on the concentration, particle size, number, and distribution of nanopesticides bound to the active ingredient (166). It is still debatable whether the release of metallic nanoparticles by microorganisms into the terrestrial environment is due to various effects of plant-derived metallic nanoparticles on the metalcore and capped phytochemicals (167). While Psquoto-Stgliiani et al. (161) confirmed that nanocapsules containing poly- $\varepsilon$-caprolactone treated with neem oil did not affect the soil microbes up to 300 days after exposure. Moreover, soils treated with nanoformulations enhanced the biomass of earthworms even up to 3 months of exposure to the formulation (168). Engineered nanomaterials can encourage surface coating and surface charge alongside other characteristics of physicochemical properties in the aquatic environment (167). As the nanopesticides may not be eco-friendly, it is necessary to understand the environmental fate and the role of surface capped plant-derived molecules in nano-specific processes (167).

\section{Toxicity to Animals}

Nanomaterials are safe at optimum size, but as they approach nanosizes, they often become toxic, especially the nonbiodegradable materials (mostly metals). By accumulating and stimulating the immune system, they can cause toxicity in mammals, plants, and soils. Moreover, they can alter the activity of detoxifying enzymes (169). Aluminosilicate used in nanotubes can stick to leaf surfaces and can increase the stability of the product, even as the ingredients are also able to stick to the body surface of the insect pest, especially in the hairs, and can in due course enter the animal's body and affects physical functions (170). Apart from direct intake, dermal contact or inhalation can also lead to nanoparticles entering the human body. In pest control operators, chronic exposure and sub-acute causes inhalation toxicity, which is very common, and sometimes this leads to major health risks.

\section{FUTURE PERSPECTIVES}

For evaluation of the threat to the environment, existing regulatory protocols are pertinent only to synthetic insecticides used for controlling tea pests. As nanoformulations have a range of properties, consequently, there is a need to plan the guidelines for the nanopesticides (171). The risk assessment framework for future applications is to be accomplished thoroughly, as in the case of synthetic pesticides the experiments used for bulk production for commercial purposes may not hold valid for nanopesticides (172). Further study on the ratio of cost/benefit, price of the nanopesticides, recognition by the large scale as well as small tea growers, techniques for safe and easy application, availability, etc. would be ideal and can be achieved through further recommending the nanopesticides for management of tea pests.

Several research findings on various agricultural crop pests showed extensive confidence that nano pesticide-based formulations viz., nano-dispersions, nano-emulsions, and nanoparticles have potential and a bright future in terms of developing more effective and safer pesticide/biopesticide formulations for controlling tea pests. Conversely, this development will go through a sturdy inspection by national and international safety regulators because of the probable toxicity concerns of nanopesticides, which are not well-understood and are not standardized yet nor explored. During synthesis, changes in methods can cause changes in shape and dimensions, and the use of such materials is associated with risks. The process of synthesis of nanomaterials is thus so important. Consequently, before the use of those materials, studies related to the risk assessment are essential, as there are no definite guidelines to use these formulations on nanomaterials, nature of toxicity of those compounds to insects and plants needs to be explored. Before nanopesticides become popular in the tea sector for controlling pests, thorough research is needed by combining analytical techniques that can characterize the surface, detect the size, nature, or shape, and quantify the adjuvant and active ingredients emanating from the formulations. By reducing the number of chemicals for tea pest management, nanopesticides will make tea production profitable and eco-friendly. Although the progress in research and development is very slow, there seems to be a promising future for nanopesticides for tea pest management.

\section{CONCLUSIONS}

Substantial crop loss occurs annually due to several notorious pests, including insects, mites, and nematodes. Tea, as a perennial monoculture crop cultivated in favorable climatic conditions, has become an ideal haven for a large number of insects and mite pests, diseases, and weeds, and this needs to be managed to avoid huge crop loss. Effective use of Nanopesticides for plant protection is an emerging research field and offers new methods to design active ingredients amid nanoscale dimensions in addition to the benefits of their formulation and delivery. Nanopesticide-based formulations $v i z$. ., nanodispersions, nano-emulsions, and nanoparticles have potential and have a bright future in the development of more effective and safer pesticide/biopesticide formulations for controlling tea pests. There seem to be intense prospects for the effective use of nanopesticides for tea pest management.

\section{DATA AVAILABILITY STATEMENT}

The original contributions presented in the study are included in the article/supplementary material, further inquiries can be directed to the corresponding author/s.

\section{AUTHOR CONTRIBUTIONS}

$\mathrm{BD}$ prepared the draft manuscript. $\mathrm{AB}$ and $\mathrm{MB}$ edited the manuscript. $\mathrm{CB}$ assisted during preparing the manuscript. All authors contributed to the article and approved the submitted version.

\section{FUNDING}

This study was performed as a part of an in-house project of the Center. 


\section{REFERENCES}

1. Li J, Zhou Y, Zhou B, Tang H, Chen Y, Qiao X, et al. Habitat management as a safe and effective approach for improving yield and quality of tea (Camellia sinensis) leaves. Sci Rep. (2019) 9:433. doi: 10.1038/s41598-018-36591-x

2. Meng Q, Li S, Huang J, Wei CC, Wan X, Sang S, et al. Importance of the nucleophilic property of tea polyphenols. J Agri Food Chem. (2019) 67:5379-3. doi: 10.1021/acs.jafc.8b05917

3. $\mathrm{Xu} \mathrm{J}, \mathrm{Xu} \mathrm{Z}$, Zheng $\mathrm{W}$. A review of the antiviral role of green tea catechins. Molecules. (2017) 22:1337. doi: 10.3390/molecules22081337

4. Miyata Y, Shida Y, Hakariya T, Sakai H. Anti-cancer effects of green tea polyphenols against prostate cancer. Molecules. (2019) 24:193. doi: 10.3390/molecules 24010193

5. Gogoi M, Borkotoky M, Borchetia S, Chowdhury P, Mahanta S, Barooah AK. Black tea bioactives as inhibitors of multiple targets of SARS-CoV-2 (3CLpro, PLpro and RdRp): a virtual screening and molecular dynamic simulation study. J Biomol Struct Dyn. (2021) 2021:124. doi: 10.1080/07391102.2021.1897679

6. Deka B, Babu A, Sarmah M. Bio-efficacy of certain indigenous plant extracts against red spider mite, Oligonychus coffeae, Nietner (Tetranychidae: Acarina) infesting tea. J Tea Sci Res. (2017) 7:28-3. doi: 10.5376/jtsr.2017.07.0004

7. Deka B, Babu A, Sarkar S. Scirtothrips dorsalis, Hood (Thysanoptera: Thripidae): a major pest of tea plantations in North East India. J Entomol Zool Stud. (2020) 8:1222-8.

8. Babu A. Pest management in tea: the south Indian scenario. Bull UPASI Tea Res Found. (2010) 55:23-30.

9. Hazarika LK, Bhyuan M, Hazarika BN. Insect Pest of tea and their management. Annu Rev Entomol. (2009) 54:26784. doi: 10.1146/annurev.ento.53.103106.093359

10. Athanassiou CG, Kavallieratos NG, Benelli G, Losic D, Usha Rani P, Desneux N. Nanoparticles for pest control: current status and future Perspectives. $J$ Pest Sci. (2018) 91:1-15. doi: 10.1007/s10340-017-0898-0

11. Smith K, Evans DA, El-Hiti GA. Role of modern chemistry in sustainable arable crop protection. Philos Trans, R Soc B. (2008) 363:623-37. doi: 10.1098/rstb.2007.2174

12. Yasur J, Usha Rani P. Environmental effects of nano silver: impact on castor seed germination, seedling growth and plant physiology. Environ Sci Pollut Res. (2013) 20:8636-48. doi: 10.1007/s11356-013-1798-3

13. Benelli G, Pavela R, Maggi F, Petrelli R, Nicoletti M. Commentary: making green pesticides greener? the potential of plant products for nanosynthesis and pest control. J Clust Sci. (2017) 28:3-10. doi: 10.1007/s10876-016-1131-7

14. Benelli G. Green synthesized nanoparticles in the fight against mosquitoborne diseases and cancer-a brief review. Enzyme Microb Technol. (2016) 95:58-68. doi: 10.1016/j.enzmictec.2016.08.022

15. Benelli G. Plant-mediated biosynthesis of nanoparticles as an emerging tool against mosquitoes of medical and veterinary importance: a review. Parasitol Res. (2016) 115:23-34. doi: 10.1007/s00436-015-4800-9

16. Mamun MSA, Ahmed M. Integrated pest management in tea: prospects and future strategies in Bangladesh. J Plant Protection Sci. (2011) 3:1-13.

17. Mamun MSA, Ahmed M, Paul SK. Integrated approaches in tea pest management for sustainable tea production. In: Proceedings of the Workshop on Tea Production Technology Updated held on 24 December, 2014 organized by Bangladesh Tea Research Institute, Srimangal, Moulvibazar and Krishi Gobeshona Foundation, BARC campus, Dhaka. (2014). p. 18-32.

18. Takagi K. Trap for monitoring adult parasites of tea pests. JARQ. (1978) 12:99-103.

19. Muraleedharan N, Selvasundaran R, Radhakrishnan B. Natural enemies of certain tea pests occurring in southern India. Insect Sci Appl. (1988) 5:647-54. doi: 10.1017/S1742758400005166

20. Agnihothrudu V. Potential of using biocontrol agents in tea. See Ref. (1999) 50:675-92.

21. Stiling $\mathrm{P}$, Cornelissen T. What makes a successful biocontrol agent? A meta-analysis of biological control agent performance. Biol Control. (2005) 34:236-46. doi: 10.1016/j.biocontrol.2005.02.017

22. Ishii T, Takatsuka J, Nakai M, Kunimi Y. Growth characteristics and competitive ability of a nucleopolyhedrovirus and an entomopoxvirus in larvae of the smaller tea tortrix, Adoxophyes honmai (Lepidoptera: Tortricidae). Biol Control. (2002) 23:96-105. doi: 10.1006/bcon.2001.0988

23. Nakai M, Kunimi Y. Granulosis virus infection of the smaller tea tortrix (Lepidoptera:Tortricidae): effects on the development of the endoparasitoid, Ascogaster reticulates (Hymenoptera: Braconidae). BiolControl. (1997) 8:7480. doi: 10.1006/bcon.1996.0483

24. Nakai M, Kunimi Y. Effect of the timing of entomopoxvirus administration to the smaller tea tortrix, Adoxophyessp. (Lepidoptera: Tortricidae), on the survival of the endoparasitoid, Ascogaster reticulates (Hymenoptera: Braconidae). Biol Control. (1998) 18:63-9. doi: 10.1006/bcon.1998.0643

25. Hazarika LK, Puzari KC. Microbials in tea pest management. In Ignacimuthu S, Sen A, editors, Microbials in Insect Pest Management. New Delhi: Oxford. (2001). p. 98-104

26. Vega FE, Posada F, Aime MC, Pava-Ripoll M, Infante F, Rehner SA. Entomopathogenic fungal endophytes. Biol Control. (2008) 46:7282. doi: 10.1016/j.biocontrol.2008.01.008

27. TRA. Pests of Tea in North-East India and Their Control. Memo. No. 27. Jorhat: Tocklai Exp. Stn. (1994). p. 231.

28. Isman MB. Botanical insecticides, deterrents and repellents in modern agriculture and an increasingly regulated world. Annu Rev Entomol. (2006) 51:45-66. doi: 10.1146/annurev.ento.51.110104.151146

29. Cranham JE. Tea pests and their control. Annu Rev Entomol. (1966) 11:491514. doi: 10.1146/annurev.en.11.010166.002423

30. Muraleedharan N. Pest control in Asia. See Ref. (1992) 115:375412. doi: 10.1007/978-94-011-2326-6_12

31. Auffan M, Rose J, Bottero JY, Lowry GV, Jolivet JP, Wiesner MR. Towards a definition of inorganic nanoparticles from an environmental, health and safety perspective. Nat Nanotechnol. (2009) 4:634-64. doi: 10.1038/nnano.2009.242

32. Sasson Y, Levy-Ruso G, Toledano O, Ishaaya I. Nanosuspensions: emerging novel agrochemical formulations. In: Ishaaya I, Nauen R, Horowitz AR, editors, Insecticides Design Using Advanced Technologies. (Berlin: Springer) (2007). p. 1-32. doi: 10.1007/978-3-540-46907-0_1

33. Niemeyer CM, Doz P. Nanoparticles, proteins, and nucleic acids: biotechnology meets materials science. Angew Chem Int Ed. (2001) 40:4128-58. doi: 10.1002/1521-3773(20011119)40:22<4128::AID-ANIE4128>3.0.CO;2-S

34. Oskam G. Metal oxide nanoparticles: synthesis, characterization and application. J Sol-Gel Sci Technol. (2006) 7:1614. doi: 10.1007/s10971-005-6621-2

35. Puoci F, Lemma F, Spizzirri UG, Cirillo G, Curcio M, Picci N. Polymer in agriculture: a review. Am, J Agric Biol Sci. (2008) 3:299314. doi: 10.3844/ajabssp.2008.299.314

36. AbduzZahir A, Bagavan A, Kamaraj C, Elango G, Abdul Rahuman A. Efficacy of plant-mediated synthesized silver nanoparticles against Sitophilus oryzae. J Biopestic. (2012) 5: 95-102.

37. Roni M, Murugan K, Panneerselvam C, Subramaniam J, Nicoletti M, Madhiyazhagan $\mathrm{P}$, et al. Characterization and biotoxicity of Hypneamusciformissynthesized silver nanoparticles as potential ecofriendly control tool against Aedes aegypti and Plutella xylostella. Ecotoxicol Environ Saf. (2015) 121:31-8. doi: 10.1016/j.ecoenv.2015.07.005

38. AbduzZahir A, Abdul Rahuman A. Evaluation of different extracts and synthesised silver nanoparticles from leaves of Euphorbia prostrata against Haemaphysalis bispinosa and Hippobosca maculata. Vet Parasitol. (2012) 187:511-20. doi: 10.1016/j.vetpar.2012.02.001

39. Jayaseelan C, Rahuman AA, Rajakumar G, Vishnu Kirthi A, Santhoshkumar T, Marimuthu S, et al. Synthesis of pediculocidaland larvicidal silver nanoparticles by leaf extract from heartleaf moonseed plant, TinosporacordifoliaMiers. Parasitol Res. (2011) 109:185-94. doi: 10.1007/s00436-010-2242-y

40. Jayaseelan C, Rahuman AA, Rajakumar G, Santhoshkumar T, Kirthi AV, Marimuthu S, et al. Efficacy of plant-mediated synthesized silver nanoparticles against hematophagous parasites. Parasitol Res. (2012) 111:921-33. doi: 10.1007/s00436-011-2473-6

41. Knowles A. Global trends in pesticide formulation technology: the development of safer formulations in China. Outlooks Pest Manag. (2009) 20:165-70. doi: 10.1564/20aug06 
42. Kah M, Beulke S, Tiede K, Hofmann T. Nanopesticides: state of knowledge, environmental fate, and exposure modeling. Crit Rev Environ Sci Technol. (2013) 43:1823-67. doi: 10.1080/10643389.2012.671750

43. Kah M, Hofmann T. Nanopesticide research: current trends and future priorities. Environ Intern. (2014) 63:22435. doi: 10.1016/j.envint.2013.11.015

44. Tadros T, Izquierdo R, Esquena J, Solans C. Formation and stability of nano-emulsions. AdvColloid Interface Sci. (2004) 108:303-3. doi: 10.1016/j.cis.2003.10.023

45. Lawrence MJ, Warisnoicharoen W. Recent advances in microemulsions as drug delivery vehicles. In: Torchilin VP, editor, Nanoparticles as Drug Carriers. London:Imperial College Press. (2006). p. 125-71. doi: 10.1142/9781860949074_0007

46. Tomlin CDS. The Pesticide Manual. 15th ed. Farnham: Surrey, England British Crop Protection Council (2009).

47. Song SL, Liu XH, Jiang JH, Qian YH, Zhang N, Wu QH. Stability of triazophos in self-nanoemulsifying pesticide delivery system. Colloid Surf A. (2009) 350:57-62. doi: 10.1016/j.colsurfa.2009.08.034

48. ObservatoryNano. Nanotechnologies for Nutrient and Biocide Delivery in Agricultural Produsction. Working paper, April 2010. (2010). Available online at: http://www.observatorynano.eu/project/filesystem/files/Controlled \%20delivery.pdf (accessed May 26, 2009).

49. Marimuthu S, Elango V, Karthic C, Thangaraj P. Trichoderma mediated green synthesis of silver nanoparticles and evaluation of its antifungal activity against Pestalotiopsis theae causing grey blight disease in tea (Camellia sinensis): a novel approach. Two Bud. (2012) 59:63-8.

50. Green JM, Beestman GB. Recently patented and commercialized formulation and adjuvant technology. Crop Prot. (2007) 26:320-7. doi: 10.1016/j.cropro.2005.04.018

51. Muller RH, Junghanns JUAH. Drug nanocrystals/nanosuspensions for the delivery of poorly soluble drugs. In: Torchilin VP, editor, Nanoparticles as Drug Carriers. London: Imperial College Press (2006). p. 30728. doi: 10.1142/9781860949074_0014

52. Du L, Miao X, Jiang Y, Jia H, Tian Q, Shen J, et al. An effective strategy for the synthesis of biocompatible gold nanoparticles using danshensu antioxidant: prevention of cytotoxicity via attenuation of free radical formation. Nanotoxicology. (2013) 7:94-300. doi: 10.3109/17435390.2011. 653415

53. Kunzmann A, Andersson B, Vogt C, Feliu N, Ye F, Gabrielsson S, et al. Efficient internalization of silica-coated iron oxide nanoparticles of different sizes by primary human macrophages and dendritic cells. Toxicol Appl Pharmacol. (2011) 253:81-93. doi: 10.1016/j.taap.2011.03.011

54. Kole C, Kole P, Randunu KM, Choudhary P, Podila R, Ke PC, et al. Nanobiotechnology can boost crop production and quality: first evidence from increased plant biomass, fruit yield and phytomedicine content in bitter melon (Momordica charantia). BMC Biotechnol. (2013) 13:37. doi: 10.1186/1472-6750-13-37

55. Rico CM, Majumdar S, Duarte-Gardea M, Peralta-Videa JR, GardeaTorresdey JL. Interaction of nanoparticles with edible plants and their possible implications in the food chain. J Agric Food Chem. (2011) 59:348598. doi: $10.1021 / \mathrm{jf104517j}$

56. Yasur J, Usha Rani P. Lepidopteran insect susceptibility to silver nanoparticles and measurement of changes in their growth, development and physiology. Chemosphere. (2015) 124:92-102. doi: 10.1016/j.chemosphere.2014.11.029

57. Lee CW, Mahendra S, Zodrow K, Li D, Tsai YC, Braam J, et al. Developmental phytotoxicity of metal oxide nanoparticles to Arabidopsis thaliana. Environ Toxicol Chem. (2010) 29:669-75. doi: 10.1002/etc.58

58. Slomberg DL, Schoenfisch MH. Silica nanoparticle phytotoxicity to Arabidopsis thaliana. Environ Sci Technol. (2012) 46:1024754. doi: 10.1021/es300949f

59. Khodakovskaya M, Dervishi E, Mahmood M, Xu Y, Li Z, Watanabe F, et al. Carbon nanotubes are able to penetrate plant seed coat and dramatically affect seed germination and plant growth. ACS Nano. (2009) 3:32217. doi: $10.1021 / \mathrm{nn} 900887 \mathrm{~m}$

60. Balalakshmi C, Gopinath K, Govindarajan M, Lokesh R, Arumugam A, Alharbi NS, et al. Green synthesis of gold nanoparticles using a cheap Sphaeranthus indicus extract: impact on plant cells and the aquatic crustacean Artemia nauplii. J PhotochemPhotobiol B Biol. (2017) 173:598605. doi: 10.1016/j.jphotobiol.2017.06.040

61. Tsuji K. Microencapsulation of pesticides and their improved handling safety. J Microencapsul. (2001) 18:137-47. doi: 10.1080/026520401750063856

62. Ghormade V, Deshpande MV, Paknikar KM. Perspectives for nanobiotechnology enabled protection and nutrition of plants. Biotechnol Adv. (2011) 29:792-803. doi: 10.1016/j.biotechadv.2011.06.007

63. Guan HN, Chi DF, Yu J, Zhang SY. Novel photodegradable insecticide $\mathrm{W} / \mathrm{TiO}(2) /$ Avermectin nanocomposites obtained by polyelectrolytes assembly. Coll Surf B Biointerf. (2011) 83:148-54. doi: 10.1016/j.colsurfb.2010.11.013

64. Casanova H, Araque P, Ortiz C. Nicotine carboxylate insecticide emulsions: effect of the fatty acid chain length. J Agric Food Chem. (2005) 53:994953. doi: 10.1021/jf052153h

65. Anjali $\mathrm{CH}$, Khan SS, Goshen KM, Magdassi S. Formulation of waterdispersible nanopermethrin for larvicidal applications. Ecotoxicol Environ Saf. (2010) 73:1932-6. doi: 10.1016/j.ecoenv.2010.08.039

66. Guan HN, Chi DF, Yu JC, Li X. A novel photodegradable insecticide: preparation, characterization and properties evaluation of nanoimidacloprid. Pestic Biochem Physiol. (2008) 92:8391. doi: 10.1016/j.pestbp.2008.06.008

67. Balaji APB, Mishra P, Suresh Kumar RS, Mukherjee A, Chandrasekaran N. Nanoformulation of poly (ethylene glycol) polymerized organic insect repellent by PIT emulsification method and its application for Japanese encephalitis vector control. Coll Surf B Biointerf. (2015) 128:3708. doi: 10.1016/j.colsurfb.2015.02.034

68. Kumar Suresh RS, Shiny PJ, Anjali CH, Jerobin J, Goshen KM, Magdassi S, et al. Distinctive effects of nanosized permethrin in the environment. Environ Sci Pollut Res. (2012) 20:2593-602. doi: 10.1007/s11356-012-1161-0

69. Guan HA, Chi DF, Yu J, Li H. Dynamics of residues from a novel nanoimidacloprid formulation in soyabean fields. Crop Prot. (2010) 29:9426. doi: 10.1016/j.cropro.2010.04.022

70. Bhan S, Mohan L, Srivastava CN. Relative larvicidal potentiality of nanoencapsulated Temephos and Imidacloprid against Culex quinquefasciatus. J Asia-Pacific Ent. (2014) 17:787-91. doi: 10.1016/j.aspen.2014.07.006

71. Bhan S, Mohan L, Srivastava CN. Combinatorial studies on thermosensitization of nanoencapsulated Temephos and Cuscuta reflexa. Int $J$ Pharmaceut Res Biosci. (2015) 4: 20-35.

72. Paula HCB, Rodrigues MLL, Ribeiro WLC, Stadler AS, Paula RCM, Abreu FOMS. Protective effect of cashew gum nanoparticles on natural larvicide from Moringa oleifera seeds. J Appl Polymer Sci. (2011) 124:1778-84. doi: 10.1002/app. 35230

73. Bhan S, Mohan L, Srivastava CN. Photosensitization of nanoencapsulated Temephos and Cuscuta reflexa combination on mosquito larvae. Int J Pharmaceut Res Biosci. (2015) 4:94-110.

74. Glenn GM, Klamczynski AP, Woods DF, Chiou B, Orts WJ, Imam SH. Encapsulation of plant oils in porous starch microspheres. I Agric Food Chem. (2010) 58:4180-4. doi: 10.1021/jf9037826

75. Kanis L, Prophiro JS, Vieira E, Nascimento M, Zepon KM, KulkampGuerreiro IC, et al. Larvicidal activity of Copaifera sp. (Leguminosae) oleoresin microcapsules against Aedes aegypti (Diptera: Culicidae) larvae. Parasitol Res. (2012) 110:1173-8. doi: 10.1007/s00436-011-2610-2

76. Paula HCB, Sombra FM, Abreu FOMS, Paula RCM. Lippia sidoides essential oil encapsulation by angico gum/ chitosan nanoparticles. J Braz Chem Soc. (2010) 21:1-8. doi: 10.1590/S0103-50532010001200025

77. Anjali $\mathrm{CH}$, Sharma Y, Mukherjee A, Chandrasekaran N. Neem oil (Azadirachtaindica) nanoemulsion- a potent larvicidal agent against Culex quinquefasciatus. Pest Manag Sci. (2012) 68:158-63. doi: 10.1002/ps.2233

78. Lai F, Wissing SA, Muller RH, Fadda AM. Artemisia arborescens L. essential oil-loaded solid lipid nanoparticles for potential agricultural application: preparation and characterization. AAPS Pharm Sci Tech. (2006) 7:E108. doi: 10.1208/pt070102

79. Yang FL, Li XG, Zhu F, Lei CL. Structural characterization of nanoparticles loaded with garlic essential oil and their insecticidal activity against Tribolium castaneum (Herbst) (Coleoptera: Tenebrionidae). J Agric Food Chem. (2009) 57:10156-62. doi: 10.1021/jf9023118 
80. Carvalho SS, Vendramin JD, Pitra MM, Florin MR. Efficacy of neem oil nanoformulations to Bemisia tabaci (Genn.) Biotype. B (Hemiptera: Aleyrodidae) SeminaCiencAgrar. (2012) 33:193-202. doi: 10.5433/1679-0359.2012v33n1p193

81. Bhan S, Mohan L, Srivastava CN. Bioefficacy of nanoencapsulated Aspergillus flavus and Cuscuta reflexa combination against anopheline and culicine larvae. Int J Pharmaceut Res Biosci. (2014) 3:481-3.

82. Hadapad AB, Hire RS, Vijayalakshmi N, Dongre TK. Sustained-release biopolymer based formulations for Bacillus sphaericus Neide ISPC-8. J Pest Sci. (2011) 84:249-55. doi: 10.1007/s10340-010-0347-9

83. Rouhani M, Samih MA, Kalantari S. Insecticide effect of silver and zinc nanoparticles against aphis nerii boyer de fonscolombe (Hemiptera: aphididae). Chilean, J Agricultural Res. (2012) 72:590-4. doi: 10.4067/S0718-58392012000400020

84. Goswami A, Roy I, Sengupta S, Debnath N. Novel applications of solid and liquid formulations of nanoparticles against insect pests and pathogens. Thin Solid Films. (2010) 519:1252-7. doi: 10.1016/j.tsf.2010.08.079

85. Barik TK, Sahu B, Swain V. Nanosilica-from medicine to pest control. Parasitol Res. (2008) 103:253-8. doi: 10.1007/s00436-008-0975-7

86. Barik TK, Kamaraju R, Gowswami A. Silica nanoparticle: a potential new insecticide for mosquito vector control. Parasitol Res. (2012) 111:107583. doi: 10.1007/s00436-012-2934-6

87. Stadler T, Buteler M, Weaver D. Novel use of nanostructured alumina as an insecticide. Pest Manag Sci. (2009) 66:577-9. doi: 10.1002/ps.1915

88. Santhoshkumar T, Rahuman AA, Rajakumar G, Marimuthu S, Bagavan A, Jayaseelan C, et al. Synthesis of silver nanoparticles using Nelumbo nucifera leaf extract and its larvicidal activity against malaria and filariasis vectors. Parasitol Res. (2011) 108:693-702. doi: 10.1007/s00436-0102115-4

89. Dinesh D, Murugan K, Madhiyazhagan P, Panneerselvam C, Kumar PM, Nicoletti $M$, et al. Mosquitocidal and antibacterial activity of greensynthesized silver nanoparticles from Aloe vera extracts: towards an effective tool against the malaria vector Anopheles stephensi. Parasitology Research. (2015) 114:1519-29. doi: 10.1007/s00436-015-4336-Z

90. Chitra G, Balasubramani G, Ramkumar R, Sowmiya R, Preumal P. Mukia maderaspatana (Cucurbitaceae) extract-mediated synthesis of silver nanoparticles to control Culex quinquefasciatus and Aedes aegypti (Diptera: Culicidae). Parasitol Res. (2015) 114:1407-15. doi: 10.1007/s00436-015-4320-7

91. Patil CD, Patil SV, Borase HP, Salunke BK, Salunkhe RB. Larvicidal activity of silver nanoparticles synthesized using Plumeria rubra plant latex against Aedes aegypti and Anopheles stephensi. Parasitol Res. (2012) 110:181522. doi: 10.1007/s00436-011-2704-x

92. Borase HP, Patil CD, Salunkhe RB, Narkhede CP, Salunke BK, Patil SV. Phyto-synthesized silver nanoparticles: a potent mosquito biolarvicidal agent. J Nanomedine Biotherapeutic Discovery. (2013) 3:111. doi: 10.4172/2155-983X.1000111

93. Ankamwar B, Damle C, Ahmad A, Sastry M. Biosynthesis of gold and silver nanoparticles using Emblica Officinalis fruit extract, their phase transfer and transmetallation in an organic solution. J Nanosci Nanotechnol. (2005) 5:1665-71. doi: 10.1166/jnn.2005.184

94. Moharrer S, Mohammadi B, Gharamohammadi RA, Yargoli M. Biological synthesis of silver nanoparticles by Aspergillus flavus, isolated from soil of ahar copper mine. Indian, J Sci Technol. (2012) 5:24434. doi: 10.17485/ijst/2012/v5i3.41

95. Raliya R, Tarafdar JC. Novel approach for silver nanoparticles synthesis using Aspergillus terreusCZR-1 mechanism perspective. J. Bionanosci. (2012) 6:12-3. doi: 10.1166/jbns.2012.1073

96. Saha P, Rajkumar K, Abraham J. Comparative study on antimicrobial property of silver nanoparticles synthesized by Fusarium equiseti and Fusarium solani. J Bionanosci. (2012) 6:28-32. doi: 10.1166/jbns.2012. 1064

97. Thirumurugan G, Shaheedha SM, Dhanaraju MD. In vitro evaluation of antibacterial activity of silver nanoparticles synthesized by using Phytopthora infestans. Int J Chem Tech Res. (2009) 1:714-6.

98. Kumar RR, Priyadarshini KP, Thamaraiselvi K. Mycogenic synthesis of silver nanoparticles by the Japanese environmental isolate Aspergillus tamarii. J Nanopart Res. (2012) 14:860. doi: 10.1007/s11051-012-0860-2
99. Gupta S, Bector S. Biosynthesis of extracellular and intracellular gold nanoparticles by Aspergillus fumigatus and Aspergillus flavus. Antonie Van Leeuwenhoek. (2013) 103:1113-23. doi: 10.1007/s10482-013-9892-6

100. Vahabi K, Mansoori GA, Karimi S. Biosynthesis of silver nanoparticles by fungus Trichoderma ressei. Insciences J. (2011) 1:65-79. doi: 10.5640/insc.010165

101. Soni N, Prakash S. Factors affecting the geometry of silver nanoparticles synthesis in Chrysosporium tropicum and Fusarium oxysporum. Am J Nanotechnol. (2011) 2:112-21. doi: 10.3844/ajnsp.2011.112.121

102. Quian Y, Yu H, He D, Yang H, Wang W, Wan X, et al. Biosynthesis of silver nanoparticles by the endophytic fungus Epicocuum nigrum and their activity against pathogenic fungi. BioproBiosys Eng. (2013) 36:16139. doi: 10.1007/s00449-013-0937-z

103. Bharathidasan R, Panneerselvam A. Biosynthesis and characterization of silver nanoparticles using endophytic fungi Aspergillus concius, Panicillium janthinellum and Phomosissp. Int J Pharma Sci Res. (2012) 3:3163-9.

104. Das SK, Dickinson C, Lafi F, Brougham DF, Marsili E. Synthesis, characterization and catalytic activity of gold nanoparticles biosynthesized with Rhizopus oryze protein extract. Green Chem. (2012) 2012:c2gc16676c. doi: 10.1039/c2gc16676c

105. Das SK, Liang J, Schmidt M, Laffir F, Marsili E. Biomineralization mechanism of gold by Zygomycete fungi Rhizopus oryze. ACS Nano. (2012) 6:616573. doi: $10.1021 / \mathrm{nn} 301502 \mathrm{~s}$

106. Soni N, Prakash S. Efficacy of fungus mediated silver and gold nanoparticles against Aedes aegypti larvae. Parasitol Res. (2011) 110:17584. doi: 10.1007/s00436-011-2467-4

107. Chan SY, Don MM. Instantaneous biosynthesis of silver nanoparticles by selected macro fungi. Australian, J Basic App Sci. (2012) 6:222-6.

108. Campbell JL, Arora J, Cowell SF, Garg A, Eu P, Bhargava SK, et al. Quasi-cubic magnetite/silica core-shell nanoparticles as enhanced MRI contrast agents for cancer imaging. PLoS ONE. (2011) 6:e21857. doi: 10.1371/journal.pone.0021857

109. Jang HR, Oh H-J, Kim J-H, Jung KY. Synthesis of mesoporous spherical silica via spray pyrolysis: pore size control and evaluation of performance in paclitaxel prepurification. Microporous Mesoporous Mater. (2013) 165:21927. doi: 10.1016/j.micromeso.2012.08.010

110. Athanassiou CG, Kavallieratos NG, Evergetis E, Katsoula AM, Haroutounian SA. Insecticidal efficacy of the enhanced silica gel with Juniperus oxycedrus L. ssp oxycedrus essential oil against Sitophilus oryzae (L) and Tribolium confusum Jacquelin du Val. J Econ Entomol. (2013) 106:190210. doi: 10.1603/EC12474

111. Wanyika H, Gatebe E, Kioni P, Tang Z, Gao Y. Mesoporous silica nanoparticles carrier for urea: potential applications in agrochemical delivery systems. J NanosciNanotechnol. (2012) 12:2221-8. doi: 10.1166/jnn.2012.5801

112. Torchilin VP. Introduction. Nanocarriers for drug delivery: needs and requirements. In: Torchilin VP, editor, Nanoparticles as Drug Carriers. London: Imperial College Press (2006). p. 1-8. doi: 10.1142/9781860948039_0001

113. Abreu FOMS, Oliveira EF, Paula HCB, de Paula RCM. Chitosan/cashew gum nanogels for essential oil encapsulation. CarbohydrPolym. (2012) 89:127782. doi: 10.1016/j.carbpol.2012.04.048

114. Nguyen HM, Hwang IC, Park JW, Park HJ. Photoprotection for deltamethrin using chitosan-coated beeswax solid lipid nanoparticles. Pest Manag Sci. (2012) 68:1062-8. doi: 10.1002/ps.3268

115. Shakil NA, Singh MK, Pandey A, Kumar J, Pankaj Parmar VS, Singh MK, et al. Development of poly- (ethylene glycol) based amphiphilic copolymers for controlled release delivery of carbofuran. J Macromol Sci A Pure Appl Chem. (2010) 47:241-7. doi: 10.1080/10601320903527038

116. Sarkar DJ, Kumar J, Shakil NA, Walia S. Release kinetics of controlled release formulations of thiamethoxam employing nanoranged amphiphilic PEG and diacid based block polymers in soil. JEnvironSciHealthATox Hazard SubstEnvironEng. (2012) 47:1701-12. doi: 10.1080/10934529.2012.6 87294

117. Adak T, Kumar J, Shakil NA, Walia S. Development of controlled release formulations of imidacloprid employing novel nanoranged amphiphilic polymers. J Environ Sci Health B. (2012) 47:217-25. doi: 10.1080/03601234.2012.634365 
118. Loha KM, Shakil NA, Kumar J, Singh MK, Adak T, Jain S. Release kinetics of beta-cyfluthrin from its encapsulated formulations in water. J Environ Sci Health B. (2011) 46:201-6. doi: 10.1080/03601234.2011.540200

119. Pankaj VS, Shakil NA, Kumar J, Singh MK, Singh K. Bioefficacy evaluation of controlled release formulations based on amphiphilicnano-polymer of carbofuran against Meloidogyne incognita infecting tomato. J Environ Sci Health B. (2012) 47:520-8. doi: 10.1080/03601234.2012.665667

120. Loha KM, Shakil NA, Kumar J, Singh MK, Srivastava C. Bioefficacy evaluation of nanoformulations of beta-cyfluthrin against Callosobruchus maculatus (Coleoptera: Bruchidae). J Environ Sci Health B. (2012) 47:68791. doi: 10.1080/03601234.2012.669254

121. Dimetry NZ, Hussein HM. Role of nanotechnology in agriculture with special reference to pest control. Int, J PharmTech Res. (2016) 9:121-44.

122. Choy JH, Choi SJ, Oh JM, Park T. Clay minerals and layered double hydroxides for novel biological applications. Appl Clay Sci. (2007) 36:12232. doi: 10.1016/j.clay.2006.07.007

123. Kim SW, Jung JH, Lamasal K, Kim YS, Min JS, Lee YS. Antifungal effects of silver nanoparticles (AgNPs) against various plant pathogenic fungi. Mycobiology. (2012) 40:53-8. doi: 10.5941/MYCO.2012.40.1.053

124. Werdin-Gonzalez JO, Yeguerman C, Marcovecchio D, Delrieux C, Ferrero A, Fernandez-Band B. Evaluation of sublethal effects of polymer-based essential oils nanoformulation on the german cockroach. Ecotoxicol Environ Saf. (2016) 130:11-3. doi: 10.1016/j.ecoenv.2016.03.045

125. Small T, Ochoa-Zapater MA, Gallello G, Ribera A, Romero FM, Torreblanca A, et al. Gold-nanoparticles ingestion disrupts reproduction and development in the German cockroach. Sci Total Environ. (2016) 565:8828. doi: 10.1016/j.scitotenv.2016.02.032

126. Sujitha V, Murugan K, Dinesh D, Pandiyan A, Aruliah R, Hwang J-S, et al. Greensynthesized CdS nano-pesticides: toxicity on young instars of malaria vectors and impact on enzymatic activities of the nontarget mud crab Scylla serrata. AquatToxicol. (2017) 188:100-8. doi: 10.1016/j.aquatox.2017.04.015

127. Mingming A, Yuncong Z, Shun H, Deguang L, Pingliang L, Jianqiang L, et al. Preparation and characterization of 1-naphthylacetic acid-silica conjugated nanospheres for enhancement of controlled-release performance. Nanotechnology. (2013) 24:035601. doi: 10.1088/0957-4484/24/3/035601

128. Song MR, Cui SM, Gao F, Liu YR, Fan CL, Lei TQ, et al. Dispersible silica nanoparticles as carrier for enhanced bioactivity of chlorfenapyr. J Pestic Sci. (2012) 37:258-60. doi: 10.1584/jpestics.D12-027

129. Debnath N, Das S, Seth D, Chandra R, Bhattacharya SC, Goswami A. Entomotoxic effect of silica nanoparticles against Sitophilus oryzae (L.). J Pest Sci. (2011) 84:99-3. doi: 10.1007/s10340-010-0332-3

130. Debnath N, Mitra S, Das S, Goswami A. Synthesis of surface functionalized silica nanoparticles and their use as entomotoxicnanocides. Powder Technol. (2012) 221:252-6. doi: 10.1016/j.powtec.2012.01.009

131. Li ZZ, Xu SA, Wen LX, Liu F, Liu AQ, Wang Q, et al. Controlled release of avermectin from porous hollow silica nanoparticles: influence of shell thickness on loading efficiency, UV-shielding property and release. J Control Release. (2006) 111:81-8. doi: 10.1016/j.jconrel.2005.10.020

132. Li ZZ, Chen JF, Liu F, Liu AQ, Wang Q, Sun HY, et al. Study of UV-shielding properties of novel porous hollow silica nanoparticle carriers for avermectin. Pest Manag Sci. (2007) 63:241-6. doi: 10.1002/ps.1301

133. Park HJ, Kim SH, Kim HJ, Choi SH. A new composition of nanosized silica-silver for control of various plant diseases. Plant Path J. (2006) 22:295302. doi: 10.5423/PPJ.2006.22.3.295

134. Elango G, Roopan SM, Dhamodaran KI, Elumalai K, Al-Dhabi NA, Arasu MV. Spectroscopic investigation of biosynthesized nickel nanoparticles and its larvicidal, pesticidal activities. J PhotochemPhotobiol, B Biol. (2016) 162:162-7. doi: 10.1016/j.jphotobiol.2016.06.045

135. Korunic Z. Diatomaceous earths, a group of natural insecticides. J Stored Prod Res. (1998) 34:89-97. doi: 10.1016/S0022-474X(97)00039-8

136. Athanassiou CG, Vayias CJ, Dimizas CB, Kavallieratos NG, Papagregoriou AS, Buchelos C. Insecticidal efficacy of diatomaceous earth against Sitophilus oryzae (L.) (Coleoptera: Curculionidae) and Tribolium confusum Du Val (Coleoptera: Tenebrionidae) on stored wheat: influence of dose rate. Temperature and exposure interval. J Stored Prod Res. (2005) 41:4755. doi: 10.1016/j.jspr.2003.12.001

137. Vayias BJ, Athanassiou CG. Factors affecting the insecticidal efficacy of the diatomaceous earth formulation Silico Sec against adults and larvae of the confused flour beetle, Tribolium confusum Du Val (Coleoptera: Tenebrionidae). Crop Prot. (2004) 23:565-73. doi: 10.1016/j.cropro.2003.11.006

138. Kavallieratos NG, Athanassiou CG, Peteinatos GG, Boukouvala MC, Benelli G. Insecticidal effect and impact on fitness of three diatomaceous earths on different maize hybrids for the ecofriendly control of the invasive storedproduct pest Prostephanus truncatus (Horn). Environ Sci Pollut Res. (2017) 2017:5. doi: 10.1007/s11356-017-9565-5

139. Ulrichs C, Krause F, Rocksch T, Goswami A, Mewis I. Electrostatic application of inert silica dust based insecticides onto plant surfaces. Commun Agric Appl Biol Sci. (2006) 71:171-8.

140. Robinson DKR, Salejova-Zadrazilova G. Nanotechnologies for Nutrient and Biocide Delivery in Agricultural Production. Working Paper Version. (2010). p. 285-97.

141. Liu Y, Tong Z, Prud'homme RK. Stabilized polymeric nanoparticles for controlled and efficient release of bifenthrin. Pest Manag Sci. (2008) 64:8083. doi: $10.1002 / \mathrm{ps} .1566$

142. WerdinGonzalez JO, Gutie'rrez MM, Ferrero AA, Fernandez Band B. Essential oils nanoformulations for stored-product pest controlcharacterization and biological properties. Chemosphere. (2014) 100:1303. doi: 10.1016/j.chemosphere.2013.11.056

143. Patil CD, Borase HP, Suryawanshi RK, Patil SV. Trypsin inactivation by latex fabricated gold nanoparticles: a new strategy towards insect control. Enzyme Microb Technol. (2016) 92:18-25. doi: 10.1016/j.enzmictec.2016.06.005

144. Perez de Luque A, Rubiales D. Nanotechnology for parasitic plant control. Pest Manag Sci. (2009) 65:540-3. doi: 10.1002/ps.1732

145. Dubey M, Bhadauria S, Kushwah BS. Green synthesis of nanosilver particles from extract of Eucalyptus hybrida (Safeda) leaf. Dig, J Nanomater Bios. (2009) 4:537-43.

146. Ki HY, Kim JH, Kwon SC, Jeong SH. A study on multifunctional wool textiles treated with nano-sized silver. J Mater Sci. (2007) 42:80204. doi: 10.1007/s10853-007-1572-3

147. Stadler T, Buteler M, Weaver D, Sofie S. Comparative toxicity of nanostructured alumina and a commercial inert dust for Sitophilus oryzae (L.) and Rhyzopertha dominica (F.) at varying ambient humidity levels. $J$ Stored Prod Res. (2012) 48:81-3. doi: 10.1016/j.jspr.2011.09.004

148. Buteler M, Sofie SW,Weaver DK, Driscoll D, Muretta J, Stadler T. Development of nanoalumina dust as insecticide against Sitophilus oryzae and Rhyzopertha dominica. Int J PestManag. (2015) 61:803. doi: 10.1080/09670874.2014.1001008

149. Lade BD, Gogle DP, Nandeshwar SB. Nano bio pesticide to constraint plant destructive pests. $J$ Nanomed Res. (2017) 6:00158. doi: 10.15406/jnmr.2017.06. 00158

150. Nuruzzaman M, Rahman MM, Liu Y, Naidu R. Nanoencapsulation, nanoguard for pesticides: a new window for safe application. J Agric Food Chem. (2016) 64:1447-83. doi: 10.1021/acs.jafc.5b05214

151. Madhusudhanamurthy J, Usha Rani P, Sambasiva Rao KRS. Organicinorganic hybrids of nano silica and certain botanical compounds for their improved bioactivity against agricultural pests. Curr Trends Biotechnol Pharm. (2013) 7:615-24.

152. Usha Rani P, Madhusudhanamurthy J, Sreedhar B. Dynamic adsorption of a-pinene and linalool on silica nanoparticles for enhanced antifeedant activity against agricultural pests. J Pest Sci. (2014) 87:191-200. doi: 10.1007/s10340-013-0538-2

153. Usha Rani P, Rajasekharreddy P. Green synthesis of silverprotein (core-shell) nanoparticles using Piper betle L. leaf extract and its ecotoxicological studies on Daphnia magna. Colloid Surf A. (2011) 389:18894. doi: 10.1016/j.colsurfa.2011.08.028

154. Rajasekharreddy P, Usha Rani P. Biosynthesis and characterization of Pd and Pt nanoparticles using Piper betle L. plant in a photoreduction method. $J$ Cluster Sci. (2014) 25:1377-88. doi: 10.1007/s10876-014-0715-3

155. Rajna S, Paschapur AU, Raghavendra KV. Nanopesticides: its scope and utility in pest management. Indian Farmer. (2019) 6:17-21.

156. Gahukar RT. Potential and utilization of plant products in pest control. In: Abrol DP, editor, Insect Pest Management: Current Concepts and Ecological Perspectives. New York, NY: Elsevier Inc. (2014). p. 12539. doi: 10.1016/B978-0-12-398529-3.00009-9 
157. Isman M. Bridging the gap: moving botanical insecticides from the laboratory to the farm. Ind Crops Prod. (2017) 110:10-4. doi: 10.1016/j.indcrop.2017.07.012

158. Boursier CM, Bosco D, Coulibaly A, Negre M. Are traditional neem extracts preparations as efficient as a commercial formulated Azadirachtin-A. Crop Prot. (2011) 30:318-22. doi: 10.1016/j.cropro.2010.11.022

159. Jiang Z, Akhtar Y, Bradbury R, Zhang X, Isman MB. Comparative toxicity of essential oil of Litsea punigens and Litsea cubeba and blends of their major constituents against the cabbage Looper, Trichoplusiani. J Agric Food Chem. (2009) 57:4833-7. doi: 10.1021/jf900274r

160. Akthar MW, Sengupta D, Chowdhury A. Impact of pesticides use in agriculture: their benefits and hazards. InterdiscToxicol. (2009) 2:112. doi: 10.2478/v10102-009-0001-7

161. Psquoto-Stgliiani T, Campos EVR, Oliveira JL, Silva CMG, BileskyJoseNGuilger M, Troost J, et al. Nanocapsules containing Neem (Azadirachta indica) oil: development, characterization and toxicity evaluation. Sci Rep. (2017) 7:5929. doi: 10.1038/s41598-017-06092-4

162. da Costa JT, Forim MR, Costa ES, de Souza JR, Mondego JM, Boca Junior AL. Effects of different formulations of neem oil- based products on control of Zabrotes subfasciatus (Boheman, 1833) (Coleoptera: Bruchidae) on beans. J Stored Prod Res. (2014) 56:49-53. doi: 10.1016/j.jspr.2013.10.004

163. Vrignaud S, Benoit JP, Saulnier P. Strategies for the nanoencapsulation of hydrophilic molecules in polymer-based nanoparticles. Biomaterials. (2011) 32:8593-604. doi: 10.1016/j.biomaterials.2011.07.057

164. Kwankua W, Sengsai S, Culeung C, Eciawong N. Sunlight decreases genotoxicity of Azadirachtin on root tip of Allium cepa and Eucresia bicolor. Ecotoxicol Environ Saf. (2010) 73:949-54. doi: 10.1016/j.ecoenv.2010.04.001

165. Liu D, Xing B. Phytotoxicity of nanoparticles: inhibition of seed germination and root growth. Environ Pollut. (2007) 150:245-50. doi: 10.1016/j.envpol.2007.01.016

166. Kookana RS, Boxall AB, Reeves PT, Ashauer R, Beulike S, Chaudhry Q, et al. Nanopesticides: guiding principles for regulatory evaluation of environmental risk. J Agric Food Chem. (2014) 62:4227-40. doi: 10.1021/jf500232f

167. Das RK, Brar SK. Plant-derived metallic nanoparticles: environmental safety and colloidal behaviour. Curr Sci. (2018) 114:2018-9. doi: 10.18520/cs/v114/i10/2018-2019
168. Kamaraj C, Gandhi PR, Elango G, Karthi S, Chung IM, Rajakumar G. Novel and environmental friendly approach: impact of Neem (Azadirachta indica) Gum Nano Formulation (NGNF) on Helicoverpa armigera (Hub.) and Spodoptera litura (Fab.). Int J Biol Macromolecules. (2018) 107:5869. doi: 10.1016/j.ijbiomac.2017.08.145

169. Hopkin SP. Ecophysiology of Metals in Terrestrial Invertebrates. London: Elsevier (1989).

170. Patil SS, Shedbalkar YY, Truskewycz BA, Chopade BA, Ball AS. Nanoparticles for environmental clean-up: a review of potential risks and emerging solutions. Environ Technol Innov. (2016) 5:10-21. doi: 10.1016/j.eti.2015.11.001

171. Kah M, Weniger AK, Hofmann T. Impacts of (Nano) formulations on the fate of an insecticide in soil and consequences for environmental exposure assessment. Environ Sci Technol. (2016) 50:10960-7. doi: 10.1021/acs.est.6b02477

172. Damalas CA, Eleftherohormos IG. Pesticide exposure, safety issues and risk assessment indicators. Int, J Environ Res Public Health. (2011) 8:140219. doi: 10.3390/ijerph8051402

Conflict of Interest: The authors declare that the research was conducted in the absence of any commercial or financial relationships that could be construed as a potential conflict of interest.

Publisher's Note: All claims expressed in this article are solely those of the authors and do not necessarily represent those of their affiliated organizations, or those of the publisher, the editors and the reviewers. Any product that may be evaluated in this article, or claim that may be made by its manufacturer, is not guaranteed or endorsed by the publisher.

Copyright (C) 2021 Deka, Babu, Baruah and Barthakur. This is an open-access article distributed under the terms of the Creative Commons Attribution License (CC BY). The use, distribution or reproduction in other forums is permitted, provided the original author(s) and the copyright owner(s) are credited and that the original publication in this journal is cited, in accordance with accepted academic practice. No use, distribution or reproduction is permitted which does not comply with these terms. 